Cahiers $d u$ MONDE RUSSE

\section{Cahiers du monde russe}

Russie - Empire russe - Union soviétique et États indépendants

$50 / 4 \mid 2009$

Varia

\title{
ЭВОЛЮЦИЯ ВЫСШЕГО КОМАНДОВАНИЯ РОССИЙСКОЙ АРМИИ И ФЛОТА ПЕРВОЙ ЧЕТВЕРТИ XViii ВЕКА
}

К ВОПРОСУ О РОЛИ ЕВРОПЕЙСКОГО ВЛИЯНИЯ ПРИ ПРОВЕДЕНИИ ПЕТРОВСКИХ ВОЕННЫХ РЕФОРМ

Evoljucija vysšego komandovanija Rossijskoj armii i flota pervoj četverti xviii veka: $k$ voprosu o roli evropejskogo vlijanija pri provedenii petrovskih voennyh reform

Evolution of Russia's military command during the first quarter of the eighteenth century. The role of European influence in the implementation of Peter's reforms

\section{Серүей в. Черников}

\section{CpenEdition}

\section{Journals}

\section{Édition électronique}

URL : https://journals.openedition.org/monderusse/9914

DOI : 10.4000/monderusse.9914

ISSN : $1777-5388$

\section{Éditeur}

Éditions de l'EHESS

Édition imprimée

Date de publication : 15 décembre 2009

Pagination : 699-735

ISBN : 978-2-7132-2261-0

ISSN : $1252-6576$

\section{Référence électronique}

Серуей в. Черников, «Эволюция высшего командования российской армии и флота первой четверти хviii века», Cahiers du monde russe [Онлайн], 50/4 | 2009, Выложить онлайн 14 janvier 2013, Наводить справки в 02 septembre 2022. URL: http://journals.openedition.org/monderusse/ 9914 ; DOl: https://doi.org/10.4000/monderusse. 9914 


\title{
ЭВОЛЮЦИЯ ВЫСШЕГО КОМАНДОВАНИЯ РОССИЙСКОЙ АРМИИ И ФЛОТА ПЕРВОЙ ЧЕТВЕРТИ ХVIII ВЕКА
}

\author{
К вопросу о роли европейского влияния при \\ проведении петровских военных реформ
}

Вспоминая о своей службе в России, бывший прусский дипломат ИоганнГоттгильф Фоккеродт с иронией заметил, что захватив в 1700 году в плен под Нарвой российских генералов «шведский король [...] оказал тем Петру I большую и существенную услугу, сняв у него таким образом с шеи большую часть старых несведущих генералов и подав ему повод снабдить свое войско более способными начальниками и привести его в гораздо лучшее состояние» ${ }^{1}$. Известно, что «Нарвская конфузия» действительно подтолкнула царя к кардинальным изменениям кадровой политики в армии, в частности, к массовому привлечению иностранных военных. Однако состав высшего командования этой эпохи изучен весьма фрагментарно ${ }^{2}$.

1. И.-Г. Фоккеродт, «Россия при Петре Великом», Неистовый реформатор, М., 2000, c. 43 .

2. Среди трудов, прямо или косвенно затрагивающих данную тематику, следует выделить статью Н.Н. Петрухинцева. В ней дается характеристика сухопутного генералитета России 1709 года. Перечень, представленный автором, содержит отдельные неточности и упущения, однако общее соотношение русских (35\%) и иноземцев $(65 \%)$ в составе сухопутного генералитета 1709 г. передано достаточно точно. С другой стороны, список 1704 г. ошибочен. Значительное число лиц из этого перечня состояли не на русской, а на саксонской службе. - Н. Н. Петрухинцев, «Немцы в политической элите России в первой половине XVIII в.», «Вводя нравы и обычаи Европейские в Европейском народе»: $\kappa$ проблеме адаптации западных идей и практик в Российской империи, М., 2008, с. 66-87. Сведения о составе генералитета в 1713 г. и первой половине 1720-х гг. содержатся в нашей работе о российской правящей элите петровской эпохи. - С. В. Черников, «Российская элита эпохи реформ Петра Великого: состав и социальная структура», Государство и общество в России XV-начала ХХ века, СПб., 2007, с. 366-386.

Весьма интересны новаторские труды М.Д. Рабиновича и Ю.Н. Смирнова, однако авторы концентрируются на смежных вопросах: развитии офицерского корпуса и 
При отсутствии обобщающих количественных данных, мнения историков о роли европейских специалистов в управлении петровской армией, ее модернизации и обучении национальных командных кадров по сути остаются гипотетическими ${ }^{3}$. Настоящая статья является результатом исследования комплекса опубликованных и архивных источников ${ }^{4}$, позволяющих подробно

гвардии (М. Д. Рабинович, «Офицерские «сказки» и послужные списки начала XVIII в.», Актовое источниковедение, М., 1979, с. 108-122; Он же, «Социальное происхождение и имущественное положение офицеров регулярной русской армии в конце Северной войны», Россия в период реформ Петра I, М., 1973, с. 133-171; Ю. Н. Смирнов, Русская гвардия в XVIII веке, Куйбышев, 1989; Он же, «Социальное происхождение чинов русской гвардии и ее комплектования в годы Северной войны», Полтава: $\kappa$ 300-летию Полтавского сражения, М., 2009, с. 229-242). По периоду дворцовых переворотов следует выделить диссертацию Г.В. Калашникова (Г. В. Калашников, Офицерский корпус русской армии в 1725-45 г2., автореферат ... к.и.н., СПб., 1999).

Неудачной попыткой оценить роль иностранного фактора при проведении петровских военных реформ следует признать недавно опубликованную работу А.В. Кутищева. Автор, в частности, безосновательно утверждает, что в 1701-1710 гг. «правительство старается ограничить численность и влияние иностранцев в управлении армии». - А. В. Кутищев, Армия Петра Великого: европейский аналог или отечественная самобытность, M., 2006, c. 397.

\section{3. Х. Баггер, Реформы Петра Великого: обзор исследований, М., 1985, с. 67-77.}

4. Основными источниками являлись: Письма и бумаги императора Петра Великого, т. 1-13, СПб., Л.-М., 1887-2003 (далее: ПиБП); Гистория Свейской войны: поденная записка Петра Великого, вып. 1-2, М., 2004 (далее: Гистория); Доклады и приговоры, состоявииеся в Правительствующем Сенате в иарствование Петра Великого, т. I-VI, СПб., 1880-1901 (далее: Доклады и приговоры); Походные журналь Петра I за 16951710, 1720-1725 г2., СПб., 1853-1855; Полное собрание законов Российской империи с 1649 года, собрание I-е, т. IV-VII, СПб., 1830 (далее: ПСЗ-I); Д. Бантыш-Каменский, Словарь достопамятных людей русской земли, ч. 1-5, М., 1836; Он же, Биографии российских генералиссимусов и генерал-фельдмаршалов, ч. 1-2, СПб., 1840; М. П. Азанчевский, История Преображенского полка, М., 1859; С. Елагин, История русского флота: период азовский, приложения, ч. 1-2, СПб., 1864; Материаль для истории русского флота, ч. 1-4, СПб., 1865-1867; Материаль Военно-ученого архива Главного штаба, т. 1, СПб., 1871; Сборник выписок из архивных бумаг о Петре Великом, т. 1-2, М., 1872; Переписка и бумаги гр. Б.П. Шереметева, 1704-1722, СПб., 1879; Ф. Ф. Веселаго, Общчий морской список, ч. 1, СПб., 1885 (далее: $O M C$ ); «Протоколы, журналы и указы Верховного Тайного совета, 1726-1730 гг.», Сборник Русского исторического общества (далее: Сб. РИО), т. 55, 56, 63, 69, 79, 84, 94, 101, СПб., 1886-1898; «Бумаги Кабинета министров императрицы Анны Иоанновны, 1731-1740 гг.», Сб. РИО, т. 104, 106, 108, 111, 114, 117, 120, 124, 126 , 130, 138, 146, Юрьев, 1898-1915; Д. Ф. Масловский, Записки по истории военного искусства в России, вып. 1, СПб., 1891; П. Карцов, История лейб-гвардии Семеновского полка, 1683-1854, ч. 1, СПб., 1892; Северная война на Ингерманландском и Финляндском mеатрах в 1708-1714, сост. А.З. Мышлаевский, М., 1893; Русский биографический словарь, т. 1-25, М., 1896-1918 (далее: РБС); П. О. Бобровский, История лейб-гвардии Преображенского полка, т. 1-2, СПб., 1900; Н. А. Воскресенский, Законодательные акты Петра I, т. 1, М.-Л., 1945; М. Д. Рабинович, Полки петровской армии, 1698-1725, М., 1977; М. В. Бабич, Государственнье учреждения XVIII века: комиссии петровского времени, М., 2003, с. 415-467; Д. О. Серов, Администрация Петра I, М., 2007; Областные правители России, 1719-1739 г2., сост. М. В. Бабич, И. В. Бабич, М., 2008; П. Бушкович, Петр Великий: борьба за власть, 1671-1725, СПб., 2008 и др. Привлечены архивные данные по петровскому и более позднему периодам: Российский государственный архив древних актов (далее: РГАДА), ф. 248, кн. 21, 33, 46, 380, 387, 391, 428, 608, 689, 1088, 1155 ; ф. 286, оп. 1 , кн. 45, 49, 82, 125, 143, 331 и др.

Среди справочников и работ, позволяющих уточнить происхождение представителей русской части генералитета, необходимо выделить следующие: П. В. Долгоруков, Российский родословный сборник, кн. 1-4, СПб., 1840-1841; Он же, Российская родословная 
проследить эволюцию состава высшего руководства армии и флота на всем протяжении первой четверти XVIII века.

Напомним вкратце предысторию петровских военных реформ в контексте общеевропейской ситуации. В середине XVI - середине XVII вв. многие европейские армии подверглись преобразованиям, которые в исторической литературе получили название «военной революции» (military revolution; термин был введен английским историком М. Робертсом в 1955 г.) $)^{5}$. Важнейшие изменения сводились к вытеснению холодного оружия огнестрельным, сокращению доли конницы, непрерывному росту пехотных формирований, распространению новых систем фортификации и крепостной артиллерии. Кроме того, реформы, проведенные Морицем Нассауским и Густавом-Адольфом в голландской и шведской армиях, привели к укреплению дисциплины, росту подвижности и маневренности войсковых соединений ${ }^{6}$.

книга, ч. 1-4, СПб., 1854-1857; П. И. Иванов, Алфавитный указатель фамилий и лиц, упоминаемых в боярских книгах, М., 1853; М. И. Семевский, Русская родословная книга, СПб., 1873; В. В. Руммель, В. В. Голубцов, Родословный сборник русских дворянских фамилий, т. 1-2, СПб., 1886-1887; Н. Н. Голицын, Материалье для полной родословной князей Голищыных, Киев, 1880; Он же, Род князей Голищыных, т. 1, СПб., 1892; А. Б. Лобанов-Ростовский, Русская родословная книга, т. 1-2, СПб., 1895; А. П. Барсуков, Списки городовых воевод и других лии воеводского управления Московского государства XVII столетия, СПб., 1902; Г. А. Власьев, Потомство Рюрика, т. I, ч. 1-3, СПб., 19061907; B. Meehan-Waters, Autocracy and Aristocracy: the Russian Service Elite of 1730, New Brunswick, New Jersey, 1982; R. Crummey, Aristocrats and Servitors: the Boyar Elite in Russia, 1613-1689, Princeton, 1983; M. Poe, The Russian Elite in the Seventeenth Century, vol. 1-2, Vammala, 2004; Правящая элита Русского государства IX-начала XVIII вв.: очерки истории, СПб., 2006; П. В. Седов, Закат Московского ияарства: иарский двор конца ХVII века, СПб., 2008; А. В. Захаров, Государев двор Петра I: публикация и исследование массовых источников разрядного делопроизводства, Челябинск, 2009 и др.

5. M. Roberts, «The Military Revolution, 1560-1660», Essays in Swedish History, L., 1967, p. 195-225. См. также: R. Hellie, Enserfment and Military Change in Muscovy, Chicago, 1971; G. Parker, The Military Revolution. Military Innovation and the Rise of the West, 1500-1800, Cambridge, 1988; M. Poe, «The Consequences of the Military Revolution in Muscovy: A Comparative Perspective», Comparative Studies in Society and History, 1996, vol. 38, № 4 (Oct.), p. 603-618; M. C. Paul, «The Military Revolution in Russia, 1550-1682», The Journal of Military History, 2004, Vol. 68. (Jan.), p. 9-46; А. В. Малов, Московские выборныле полки солдатского строя в начальный период своей истории, 1656-1671 г2., М., 2006, с. 30-58; В. В. Пенской, «Военная революция в Европе XVI-XVII веков и ее последствия», Новая и новейшая история, 2005, № 2, с. 194-206; Он же, От лука к мушкету. Вооруженные силь Российского государства во 2-й половине XV-XVII вв.: проблемы развития, Белгород, 2008. Многие авторы указывают на более широкие временные рамки «военной революции» в Европе.

6. Воздействие «военной революции» не ограничивалось исключительно военной областью. Преобразования в армии были тесно связаны с политическими, социальными и экономическими процессами общего характера. Они сыграли определенную роль в укреплении абсолютизма, бюрократизации административного аппарата, распространении «регулярности» из военной сферы на гражданскую. Произошло снижение военного значения дворянской конницы, увеличился приток в вооруженные 
В Московском государстве активные военные преобразования также начались в середине XVI столетия. Было создано стрелецкое войско, увеличилась численность пехоты, подверглись ограничению местнические споры в армии. Все это позволяет согласиться с мнением о вступлении России в начальный этап «военной революции». Тем не менее кардинальных перемен в эту эпоху не произошло: основой русской армии продолжала оставаться поместная конница. В начале 1570 -х гг. она составляла около 70\% войска 7 . Отставание России от Европы в ходе «военной революции» объяснялось рядом внутренних и внешних причин. Так, основным противником московской армии на протяжении длительного времени была татарская конница, для борьбы с которой большие массы пехоты и артиллерия были практически бесполезны, a ручное огнестрельное оружие оставалось недостаточно совершенным для использования в конном бою. Лишь с середины XVI столетия, когда Москва начала активные военные действия против Ливонского ордена, Речи Посполитой и Швеции, стало очевидно, что традиционная дворянская конница перестала справляться со своими задачами: Ливонская война (1558-1583 гг.) закончилась для России поражением. Однако низкая доходность сельского хозяйства, сравнительная бедность населения, неразвитость торговли и инфраструктуры, малочисленность аппарата управления не позволяли проводить широкомасштабные реформы. В середине XVI столетия Московское государство оказалось неспособно оплатить такие преобразования в военной сфере, на которые были вынуждены идти европейские державы, а глубокие социально-экономические и политические потрясения второй половины XVI - начала XVII вв. приостановили дальнейшую модернизацию ${ }^{8}$.

Перед началом Смоленской войны (1632-1634гг.) московскоеправительство решило обратиться к европейскому опыту и приступило к формированию полков «нового (иноземного) строя». Для этих целей впервые был предпринят широкомасштабный наем иностранных военных специалистов. Однако скорый проигрыш в Смоленской войне помешал воспользоваться плодами нововведений. Следующий этап в развитии полков «нового строя» (солдатских, драгунских, гусарских и рейтарских) пришелся на время русско-польской войны 1654-67 гг. Ряды «начальных людей» русской армии заполнялись иностранцами 9 . Найти желающих среди европейских офицеров оказалось

силы лиц из низших сословий, выросла численность армий, что привело к размыванию сословных границ между «рыцарским классом» и остальной частью общества. Колоссальные затраты на модернизацию армий сопровождались постоянным ростом налогообложения и усилением социальных конфликтов.

7. В. В. Пенской, От лука к мушкету..., с. 102-103.

8. О российском опыте проведения военных реформ в период Смуты см.: Г. Н. Бибиков, «Опыт военной реформы 1609-1610 гг.», Исторические записки, т. 19, М., 1946, с. 3-16; О. А. Курбатов, «Наемный корпус Делагарди на службе царя Василия Шуйского», Цейхгауз, 2002, вып. 19, № 3, с. 4-6; В. В. Пенской, «Попытка военных реформ в России начала XVII века», Вопросы истории, 2003, № 11, с. 127-138.

9. А. В. Малов, Московские выборные полки..., с. 30-58; А. В. Чернов, Вооруженные силь Русского государства в XV-XVII вв., М., 1954, с. 149-151. Основная масса служилых 
нетрудно, поскольку после Вестфальского мира 1648 г. в Европе сложился переизбыток военных кадров. Возможность быстрой карьеры, регулярно выплачиваемое жалование (сравнительно со многими европейскими армиями), более низкий уровень цен и относительная веротерпимость делали Московское государство достаточно привлекательным для службы. Бурный рост наемничества в Германии в период Тридцатилетней войны (1618-48 гг.) привел к тому, что именно немцы стали основным контингентом, приезжавшим в Россию. Много было и английских роялистов, покинувших родину после гражданской войны и казни короля Карла I. Подавляющее большинство иностранцев, служивших в России, приезжало из тех стран, где был распространен протестантизм. Вероятно, это был сознательный выбор российского правительства, в глазах которого католицизм, обладавший строгой церковной иерархией и занимавший активную позицию в распространении своего вероучения, представлял угрозу для православной церкви. Часть иноземцев, принявших православие и отличившихся на военной службе, получила чины государева двора ${ }^{10}$.

В результате преобразований, проведенных в царствование Алексея Михайловича, российская армия существенно изменилась. К началу 1680-х гг. полки «нового строя» составляли до 75\% всех ратных людей полковой службы и являлись наиболее боеспособной частью вооруженных сил. За полвека общее количество ратных людей выросло со 100 тыс. до 200 тыс. Численность походного войска увеличилась в 5-6 раз. Доля пехоты в армии за 1630-1680 гг. выросла с 30 до 60\%, а удельный вес поместной конницы сократился с 40 до $20 \%{ }^{11}$. Большинство дворян и детей боярских «сотенной службы» были включены в состав кавалерии рейтарского типа ${ }^{12}$. Однако даже ограниченная модернизация потребовала огромных финансовых затрат. По подсчетам П.Н. Милюкова, расходы на армию в течение XVII столетия выросли в 2,5 - 4 раза. К 1680 г. на военные нужды уходило более $60 \%$ бюджета страны ${ }^{13}$. Постоянный недостаток средств на содержание новых полков правительство компенсировало с помощью земельных раздач, которые во многих случаях заменяли собой казенное денежное и хлебное довольствие. Перевод полков «нового строя» на самообеспечение, роспуск большей части их состава после завершения военных действий вели к резкому снижению боевого потенциала.

людей по-прежнему состояла из дворянства, детей боярских и представителей тяглого населения, привлекавшихся к ратному делу в принудительном порядке.

10. М. П. Лукичев, Н. М. Рогожин, «Боярская книга 1658 года (источниковедческий анализ)», Боярская книга 1658 года, М., 2004, с. 6-7; Правящзая элита русского государства..., с. 426.

11. А. В. Чернов, указ. соч., с. 130-131, 168-169, 185; В. В. Пенской, От лука к мушкету..., c. $228-230$.

12. См.: А. В. Малов, «Конница нового строя в русской армии в 1630-1680-е годы», Отечественная история, 2006, № 1, с. 118-131.

13. П. Н. Милюков, Государственное хозяйство России в первой четверти ХVIII столетия и реформа Петра Великого, СПб., 1905, с. 36, 39-40. 
Полки «иноземного строя» фактически превращались в полурегулярные формирования, сочетавшие в себе как европейские военные новации, так и русские традиции содержания армии в условиях ограниченных финансовых возможностей. Таким образом, к концу XVII века «военная революция» в России не была завершена.

$$
* * *
$$

Новый этап реформ и создание регулярной армии совпали с периодом Северной войны. Как уже было отмечено выше, модернизация вооруженных сил сопровождалась значительными переменами в составе высшего командования армии и флота. В общей сложности, нами было выявлено 203 человека $^{14}$, носивших в первой четверти XVIII века воинские чины 1-5 классов Табели о рангах (см. табл. 1).

Таблица 1

Общая численность выспих армейских и флотских чинов в 1700-1725 гт.

\begin{tabular}{|l|r|r|r|r|r|r|r|r|}
\cline { 2 - 10 } \multicolumn{1}{c|}{} & \multicolumn{2}{c|}{ Всего } & \multicolumn{2}{c|}{$\begin{array}{c}\text { Сухопутная } \\
\text { служба }\end{array}$} & \multicolumn{2}{c|}{ Морская служба } & \multicolumn{2}{c|}{$\begin{array}{c}\text { Сухопутная и } \\
\text { морская служба }\end{array}$} \\
\cline { 2 - 10 } \multicolumn{1}{c|}{} & абс & \multicolumn{1}{c|}{$\%$} & абс. & $\%$ & абс. & $\%$ & абс. & $\%$ \\
\hline Русских & 75 & 37 & 66 & 88 & 5 & 7 & 4 & 5 \\
\hline Иноземцев & 128 & 63 & 102 & 80 & 26 & 20 & 0 & 0 \\
\hline Итого & 203 & 100 & 168 & 83 & 31 & 15 & 4 & 2 \\
\hline
\end{tabular}

Как следует из таблицы, среди высшего руководства армии и флота России этого периода 128 человек являлись иноземцами, а 75 - русскими. Основным критерием для дифференциации являлись место рождения и конфессиональный статус. К иноземцам отнесены лица, родившиеся за пределами России. Потомки выходцев из других государств, проживавшие на территории России уже в XVII веке, считались русскими только в случае наличия сведений о их переходе в православие до начала царствования Петра I.

Структура чинов сухопутного генералитета может быть достаточно полно представлена по Штатам 1711, 1712, 1720 гг., Воинскому уставу 1716 г. и Табели о рангах 1722 г. ${ }^{15}$ Поскольку в наиболее четкой и завершенной форме иерархия воинских чинов отражена в Табели о рангах, то мы использовали

14. См. приложение к статье.

15. ПСЗ-I, т. IV, № 2319, с. 590-627, № 2480, с. 792-801; т. V, № 3006, с. 203-453; т. VI, № 3511, с. 127, № 3890, с. 486-493; т. XLIII, ч. I, Книга Штатов, отдел. I, с. 1-38. См. также: Государственность России: словарь-справочник, кн. 5, ч. 1-2, М., 2005. 
данный законодательный акт и его терминологию (а также нумерацию рангов) для классификации генералитета всего петровского правления. По Табели о рангах к первому классу относился чин генерал-фельдмаршала, ко второму генералы от кавалерии и инфантерии (генерал-аншефы или полные генералы) и генерал-фельдцейхмейстер, к третьему - генерал-лейтенанты (генералпоручики), генерал-кригс-комиссар, к четвертому - генерал-майоры, гвардии полковники, к пятому - бригадиры, обер-штер-кригс-комиссар, генералпровиантмейстер, гвардии подполковники, полковники от артиллерии ${ }^{16}$.

Дальнейший анализ состава генеральского корпуса показывает, что главным параметром его эволюции в течение первой четверти XVIII века было соотношение русских и иноземцев.

16. Среди чинов, не включенных в Табель о рангах, были следующие: генералфельдмаршал-лейтенант, инженер-генерал (генерал-инженер), генерал-комиссар, генерал-пленипотенциар-кригс-комиссар, генерал-квартирмейстер. Чин генералфельдмаршала-лейтенанта (в нем находились бар. Г. Гольц и бар. Г.-Б. Огильви) может быть приравнен к первому классу Табели, поскольку по Воинскому уставу лицо, состоявшее в этом чине, являлось ближайшим помощником генерал-фельдмаршала, в его отсутствие принимало на себя обязанности главнокомандующего армией и имело первенство надполными генералами. Чин инженер-генерала, который носил Ж.-Г. Ламбер де Герен, фактически являлся аналогом полного генерала (второй класс), служившего по инженерной части. Чины генерал-комиссара (с 1700 г.) и генерал-пленипотенциар-кригскомиссара (с 1711 г.) носил один и тот же человек - кн. Я.Ф. Долгоруков. Они приравнены к третьему классу Табели о рангах. Чин генерал-квартирмейстера (в нем числились В.А. Апухтин, бар. Ф.-Р. Гольц и кн. А.Ф. Шаховской) отнесены Штатами 1720 г. к генералмайорскому рангу (четвертый класс). Тот же ранг упоминается в патенте, выданном в 1708 г. Ф.-Р. Гольцу: «а ранг ему и трактамент иметь против генерала-маеора молодшего». - ПСЗ-I, т. IV, № 1766, с. 14-15, № 2412, с. 724; т. V, № 3006, с. 219-220; т. XLIII, ч. I, Книга Штатов, отдел. I, с. 16; Доклады и приговоры..., т. 1, с. 326; ПиБП, т. 6, с. 633-634; т. 11, вып. 2, с. 96, 97, 409; Государственность России..., кн. 5, ч. 1, с. 137-138, 150, 369-370; Д. Н. Бантыш-Каменский, Биографии российских генералиссимусов ..., ч. 1, с. V.

Следует сделать оговорку относительно места гвардейских чинов в военной иерархии петровского времени. Несмотря на то, что гвардия была элитой русской армии и получала повышенное жалование и довольствие, командиры гвардейских полков в течение Северной войны не имели законодательно закрепленного преимущества в чинах перед одноименными армейскими. Старшинство гвардейских чинов в два класса было зафиксировано только в Табели о рангах. Однако, обращая внимание на привилегированный характер гвардейской службы и для сохранения единой чиновной структуры на протяжении всего изучаемого времени, мы при подсчетах (как до, так и после 1722 года) условно приравнивали чин гвардии полковника к рангу армейского генерал-майора, а чин гвардии подполковника (если имелись сведения, что именно он был старшим командиром полка) - к рангу бригадира.

В том случае, если какое-либо лицо в течение одного и того же года носило последовательно или одновременно несколько чинов разного ранга, при расчетах учитывался старший. Генералы, получившие полную отставку и не находившиеся ни на действительной армейской, ни на административной службе, при подсчетах не учтены. Из подсчетов также исключены данные о чинах, в которых проходил службу государь Петр I. 
Pис. 1

Соотношение русских и иноземцев в составе российского генералитета в 1700-1725 гт.

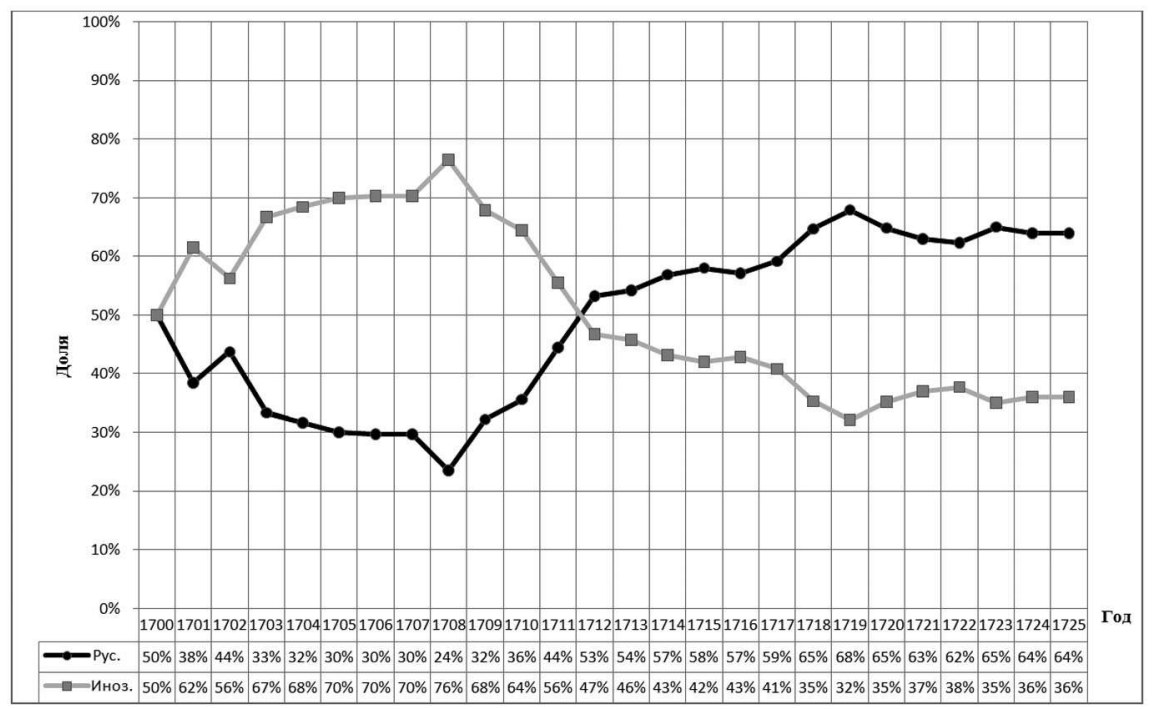

Представленные данные (см. рис. 1) позволяют выделить в развитии генералитета три периода. Первый период (1700-1702 гг.) пришелся на начало Северной войны: от поражения под Нарвой до издания манифеста 1702 г. о призыве иноземцев на русскую службу. В течение второго периода (1702-1708 гг.) осуществлялось целенаправленное привлечение иностранного генералитета на российскую службу. К 1708 г. его доля достигла максимума (76\% иноземцев против 24\% русских). Третий период (1709-1725 гг.) начался после победы под Полтавой. Приобретенный боевой опыт и успехи российской армии позволили внести коррективы в кадровую политику и перейти к постепенной замене иностранных генералов. С 1712 г. русские начали преобладать в составе высшего командования, а к концу правления Петра I их доля выросла до 64\%.

Рассмотрим эволюцию состава сухопутного генералитета более подробно. После прихода Петра I к власти в 1689 году, ближайшее окружение государя на протяжении целого десятилетия почти полностью состояло из представителей знати, родственников царя и военных-иноземцев. Как справедливо отметил Р. Крамми, состав лиц, оказывавших в этот период реальное влияние на управление страной, был более аристократичным, чем сама Боярская дума ${ }^{17}$. Среди высшего военного командования также преобладали члены знатных фамилий и тех родов, которые закрепились в Думе при первых Романовых: И.И. Бутурлин, А.М. и Ф.А. Головины, кн. Ф.Ю. Ромодановский, А.С. Шеин,

17. П. Бушкович, указ. соч., с. 173-215; R. Crummey, «Peter and the Boyar Aristocracy, 16891700», Canadian-American Slavic Studies, 1974, vol. 8, № 2, p. 274-287. 
Б.П. Шереметев. Разрядный приказ возглавлял Т.Н. Стрешнев. Наибольшим авторитетом среди генералов-иноземцев пользовались швейцарец Ф.Я. Лефорт и шотландец П.И. Гордон.

После возвращения Петра из Великого посольства окончательно сложился союз России, Дании и Саксонии против Швеции. Подготовка к войне шла достаточно быстрыми темпами. Объявление в 1699 г. набора вольных и даточных людей позволило России в короткий срок сформировать три дивизии (генеральства) общей численностью около 30 тыс. человек под командованием А.М. Головина, А.А. Вейде и кн. А.И. Репнина. Наиболее слабым местом новых полков были некомплектность и низкий уровень подготовки среднего офицерского звена, набранного из московских дворянских чинов. Общая оценка боеспособности регулярной армии в тот период, данная в официальной «Гистории Свейской войны», была такова: «как афицеры, так и салдаты, все двоелетние суть были рекруты» ${ }^{18}$.

В 1699-начале 1700 гг. умерли Ф.Я. Лефорт, П.И. Гордон, А.С. Шеин и в руководстве армией произошли перестановки. Тем не менее, к кардинальным переменам в составе командования они не привели. Если рассмотреть состав генералитета 1700-1702 гг. (первый этап), мы увидим, что к началу Северной войны в высшем командном составе сложилось примерное равенство русских и иноземцев. Однако в чинах от генерал-майора и старше преобладали русские и представители тех иноземных фамилий, которые переселились в Россию еще до начала правления Петра I.

В 1700 г. в чине генерал-фельдмаршала находились ближний боярин Федор Алексеевич Головин и незадолго до этого принятый на русскую службу по рекомендации короля Августа II голландец герцог Карл-Евгений де Кроа. Именно он командовал российскими войсками под Нарвой после спешного отъезда в Москву Петра I и Ф.А. Головина. Полных генералов было четверо: комнатные стольники А.М. Головин и кн. А.И. Репнин, боярин Б.П. Шереметев и родившийся в Москве голландец А.А. Вейде. Русской артиллерией командовал сын царя Имеретии и Кахетии Арчила II, близкий друг Петра I генерал-фельдцейхмейстер царевич А.А. Имеретинский. В чине генерал-комиссара состоял боярин кн. Я.Ф. Долгоруков. Генерал-майорами являлись комнатный стольник И.И. Бутурлин, боярин кн. И.Ю. Трубецкой, а также иноземцы старого выезда Я.В.Брюс, Х.-Г. Ригеман, А.В. Шарф. Русским условно можно считать генерал-майора Ю.А. Фамендина, лифляндского дворянина, чьи предки приняли православие еще при Алексее Михайловиче. Преображенским полком под Нарвой командовал курляндец полковник И.-Э. Блюмберг. В чинах полковников артиллерии служили «цесарцы» К. де. Граге и бар. Э.-Ф. Боргсдорф. На должность генерал-провиантмейстера

18. М. Д. Рабинович, «Формирование регулярной русской армии накануне Северной войны», Вопросы военной истории России: XVIII и первая половина XIX веков, М., 1969, с. 221-233; Гистория..., вып. 1, с. 198-199; А. А. Востоков, «О делах Генерального двора», Описание документов и бумаг, хранящихся в Московском архиве Министерства Юстиции, кн. 5, М., 1888, отдел. II, с. 1-41. 
в феврале 1700 г. был назначен сын фаворита царя Федора Алексеевича окольничий С.И. Языков.

Таким образом, подавляющее большинство русских генералов этого времени являлись выходцами из среды боярской аристократии, а новые иноземные чины они получили незадолго до начала Северной войны. Среди иноземцев преобладали старовыезжие. Лишь несколько человек имели опыт службы в европейских армиях конца XVII века: герцог де Кроа - в датской, австрийской и саксонской, де Граге и бар. Боргсдорф - в австрийской.

Как уже было отмечено, основной причиной изменений в составе российского генералитета 1700-1702 гг. стало поражение под Нарвой. В плен к шведам попали К.-Е. Кроа, А.М. Головин, А.А. Вейде, А.А. Имеретинский, Я.Ф. Долгоруков, И.И. Бутурлин, И.Ю. Трубецкой, И.-Э. Блюмберг ${ }^{19}$. Был убит К. де Граге. Кроме того, очень высокими оказались потери среди командующих полками (около 40\%) ${ }^{20}$. К.-Е. Кроа и А.А. Имеретинский уже не вернулись в Россию. Первый умер в Ревеле в 1702 г., а второй - на острове Питео в 1711 г. Остальные были выведены из строя на достаточно продолжительный период. И.И. Бутурлин и А.А. Вейде были освобождены из плена в 1710 г., А.М. Головин и И.Ю. Трубецкой - только в 1718 г., а Я.Ф. Долгорукову удалось бежать в 1711 г.

«Нарвская конфузия» продемонстрировала достаточно низкий профессиональный уровень российского генералитета слабо знакомого с европейским военным опытом того времени ${ }^{21}$. Тем не менее, некоторым удалось сохранить свои посты. Так, генерал-фельдмаршал, адмирал гр. Ф.А. Головин вплоть до своей смерти в 1706 г. являлся наиболее влиятельным лицом в российском правительстве. Хотя по сути Головин был человеком невоенным, он продолжал осуществлять общее руководство армией и флотом. Кроме того, Головин возглавлял Посольский приказ и целый ряд других учреждений ${ }^{22}$. Б.П. Шереметев, пользовавшийся большим авторитетом в среде аристократии, в 1701 г. был произведен в генерал-фельдмаршалы. Несмотря на достаточно сложные отношения с Петром $\mathrm{I}^{23}$, он до своей кончины в 1719 г. неизменно занимал руководящие посты в полевой армии. А.И. Репнин всю Северную войну прошел в чине генерал-аншефа и только в

19. Гистория..., вып. 1, с. 208-209. Относительно И.-Э. Блюмберга в «Гистории» есть помета: «сей не яко пленник, но более своею волею, оставя свою команду, к неприятелю ушел наперед» (с. 208).

20. Подсчет Н.Н. Петрухинцева. - Н. Н. Петрухинцев, указ. соч., с. 69.

21. В «Гистории Свейской войны» Петр I достаточно высоко оценил значение нарвского поражения для последующего развития российской армии: «[...] ныне, когда о том подумать, во истинну не гнев, но милость божию исповедати долженствуем, ибо, ежели б нам тогда над шведами виктория досталась, будучи в таком неискустве во всех делах, как воинских, так и политических, то в какую б беду после нас оное щастие вринуть могло». -Гистория..., вып. 1, с. 209.

22. П. Бушкович, указ. соч., с. 216-258.

23. См.: А. И. Заозерский, «Фельдмаршал Шереметев и правительственная среда Петровского времени», Россия в период реформ Петра I, М., 1973, с. 172-198. 
1724 г. был пожалован в генерал-фельдмаршалы. Генерал-аншеф и стольник И.М. Кольцов-Мосальский (ум. в 1707 г.) возглавлял пограничные гарнизоны на юге России и являлся белгородским «губернатором».

Помимо производства Б.П. Шереметева в генерал-фельдмаршалы, наиболее важным кадровым назначением 1701 года стало приглашение на русскую службу в чине инженера-генерала француза Ж.-Г. Ламбера де Герена. Договор с Ламбером был подписан в ноябре 1701 г. русским послом в Варшаве кн. Г.Ф. Долгоруковым. В 1702-1703 гг. Ламбер участвовал в осаде Нотебурга, Ниеншанца, а также в строительстве Петропавловской крепости ${ }^{24}$.

Второй этап эволюции высшего командного состава сухопутной армии начался после издания «Манифеста о вызове иностранцев в Россию» 16 апреля 1702 г. $^{25}$ Это был период активного обновления генералитета. В основу указанного документа были положены предложения лифляндца ИоганнаРейнгольда Паткуля, обращавшего внимание Петра I на необходимость кадровых изменений. Сам Паткуль, назначенный чрезвычайным посланником при польском дворе, получил чин российского тайного советника и был наделен полномочиями «приглашать в царскую службу всех чинов людей и царским именем заключать с ними договоры» ${ }^{26}$. Четкая установка Петра I на заимствование европейского военного опыта давала иностранцам возможность получать более высокие чины уже при поступлении на службу и способствовала их дальнейшему карьерному росту. Иноземцам «нового выезда» также полагалось повышенное жалование ${ }^{27}$. Число желающих по всей видимости было достаточно большим. Так, в 1707 г. воинский советник русской службы бар. Генрих Гюйссен писал тайному секретарю П.П. Шафирову: «рекомендации и прибегание ко мне иноземских офицеров столь велико, что едва покою от них имею, и [...] по последней мере не буду многих рекомендовать» ${ }^{28}$.

Двое из приглашенных иностранцев получили в 1702-1708 гг. чины генералфельдмаршала. Так, в ноябре 1702 г. И.-Р. Паткулем и российским послом в Вене кн. П.А. Голицыным была заключена «капитуляция» с австрийским генерал-фельдмаршалом-лейтенантом (шотландцем по происхождению) бар. Георгом-Бенедиктом Огильви. Из-за взаимных претензий по поводу

24. ПиБП, т. 2, с. 84, 361, 397, 400; Н. Н. Бантыш-Каменский, Списки кавалерам российских императорских орденов, М., 2006, с. 62-63. В 1706 г. Ламбер не вернулся из-за границы, куда был направлен для приглашения иностранных инженеров на русскую службу.

25. ПСЗ-I, т. IV, № 1910, c. 192-194.

26. ПиБП, т. 2, с. 39-51, 337-340; Н. Устрялов, История ияарствования Петра Великого, т. IV, ч. 2, СПб., 1863, с. 234-237. После заключения саксонцами Альтранштадтского мира 1706 г. И.-Р. Паткуль был передан шведам, а в октябре 1707 г. - казнен (ПиБП, т. 2, с. 684; т. 3 , с. $4,5,64,196,365,416,534,537,714$; т. 4, с. 1216; т. 9, с. 1275 ; Походный журнал Петра, за 1704 г., с. 20; Гистория..., вып. 1, с. 256, 257, 267, 268; Б. Савинков, «Паткуль Иоганн-Рейнгольд», РБС, т. Павел-Петрушка, с. 373-377).

27. М. Д. Рабинович, «Социальное происхождение...», с. 156-157.

28. ПиБП, т. 5 , с. 575. 
выполнения условий первоначального договора, приезд Огильви постоянно откладывался. Он прибыл в Россию в мае 1704 г., получил чин генералфельдмаршала-лейтенанта (второго фельдмаршала) русской службы и командовал войсками при штурме Нарвы. Из-за постоянных конфликтов Огильви с Б.П. Шереметевым и А.Д. Меншиковым шотландец в 1706 г. был отправлен в отставку. В 1707 г. на службу в чине генерала от кавалерии был принят уроженец Бранденбурга саксонский генерал-майор бар. Генрих Гольц. В том же году он получил чин генерал-фельдмаршала-лейтенанта. В 1710 г. по обвинениям, выдвинутым А.Д. Меншиковым, он был отдан под суд и в 1711 г. был вынужден уехать из России.

Среди генерал-аншефов новыми лицами в 1702-1708 гг. стали саксонец бар. Л.-Н. Алларт (поступил на русскую службу в чине генерал-лейтенанта после возвращения из шведского плена в $1706 г_{.}^{29}$ ) и фаворит государя кн. А.Д. Меншиков. В чине генерал-лейтенанта за период с 1702 до 1708 г. находилось в общей сложности 18 лиц. Только двое генерал-лейтенантов были русскими: кн. А.Д. Меншиков и кн. М.М. Голицын. Остальные 16 человек имели иноземное происхождение: бар. Л.-Н. фон Алларт, Р.-Х. Боур, Я.В. Брюс, Венедигер, А.-Ф. Гейн, И.-Х. Гейнске, кн. Ф. Гессен-Дармштадтский, бар. П. Дальбон, фон Корренберг, И.-Р. фон Паткуль, Г. Пфлуг, бар. К.-Э. Ренне, С. Ренцель, бар. Г.-Г. фон Розен, И.И. Чамберс, А.А. фон Шенбек. Из этого перечня только двое (Я.В. Брюс, И.И. Чамберс) являлись иноземцами старого выезда, предки которых служили в России еще в XVII столетии. Подавляющее большинство остальных были выходцами из Германии и Прибалтики. Особенно стремительный карьерный рост иностранцев наблюдался в кавалерийских частях (бар. К.-Э. Ренне, Р.Х. Боур, С. Ренцель, бар. Г.-Г. фон Розен, кн. Ф. Гессен-Дармштадтский, И.-Х. Гейнске, Г. Пфлуг).

Общие тенденции развития российского генералитета в 1700-1708 гг. можно проследить по таблице 2. Как видим, после поражения под Нарвой в высших чинах (генерал-фельдмаршалы и генерал-аншефы) либо соблюдался паритет между иноземцами и русскими, либо преобладали последние. Несмотря на то, что Петр нуждался в квалифицированных командирах, назначение иностранцев на руководящие посты в армии осуществлялось с крайней осторожностью. Зато в более низких рангах (от бригадира до генерал-поручика) иноземцы доминировали, причем с течением времени их численность постоянно росла. К 1708 г. в чинах генерал-поручика и генералмайора было около 90\% иноземцев, среди бригадиров - 63\%. В целом, к этому времени генералитет был на $24 \%$ русским и на $76 \%$ состоял из иноземцев. Таким образом, кадровая политика данного периода привела к тому, что стратегическое планирование военных операций и общее руководство российской армией было сосредоточено в руках государя и узкой группы генералитета из числа русских и иностранцев. Тактическое руководство и 
ЭВОЛЮЦИЯ ВЫСШЕГО КОМАНДОВАНИЯ РОССИЙСКОЙ АРМИИ И ФЛОТА (1700-1725) 711

\begin{tabular}{|c|c|c|c|c|c|c|c|c|c|c|c|}
\hline \multirow{13}{*}{ 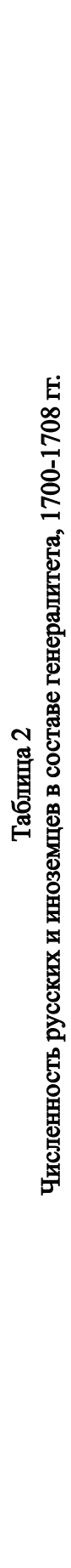 } & \multirow{2}{*}{ 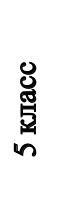 } & 兽 & $N$ & $N$ & $N$ & $N$ & $\sim$ & $N$ & 0 & $r$ & 으 \\
\hline & & 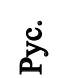 & - & - & 0 & 0 & 0 & $\sim$ & $n$ & $m$ & 6 \\
\hline & \multirow{2}{*}{ 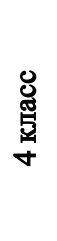 } & 突 & $\nabla$ & $n$ & 0 & 0 & 0 & $\simeq$ & $\simeq$ & $=$ & $\beth$ \\
\hline & & 远 & $m$ & - & $n$ & $N$ & - & $\sim$ & $m$ & $\nabla$ & $N$ \\
\hline & \multirow{2}{*}{ 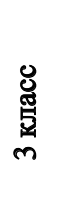 } & 密 & 0 & 0 & 0 & $n$ & $m$ & $n$ & 6 & 6 & 으 \\
\hline & & 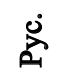 & - & 0 & 0 & 0 & - & 0 & 0 & 0 & - \\
\hline & \multirow{2}{*}{ 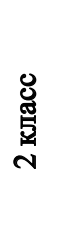 } & 离 & $N$ & - & - & - & - & - & - & - & - \\
\hline & & ¿̇ & $m$ & - & $N$ & $N$ & $N$ & $m$ & $n$ & $n$ & $N$ \\
\hline & \multirow{2}{*}{$\begin{array}{l}\text { 芭 } \\
\text { 疋 } \\
-\end{array}$} & 㐭 & - & 0 & 0 & 0 & - & - & - & - & - \\
\hline & & ᄅ. & - & $N$ & $N$ & $N$ & $\sim$ & $N$ & $N$ & - & - \\
\hline & \multirow{2}{*}{ 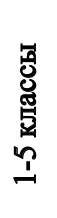 } & ஜ̊ํㅛ & $a$ & $\infty$ & $a$ & $\simeq$ & $\cong$ & $\vec{\sim}$ & $\stackrel{\sim}{\sim}$ & $\stackrel{\sim}{\sim}$ & ले \\
\hline & & ¿ & $a$ & $n$ & $r$ & 0 & 0 & $a$ & $\Xi$ & $=$ & $\simeq$ \\
\hline & \multicolumn{2}{|c|}{ 占 } & $\stackrel{8}{\beth}$ & $\stackrel{ }{2}$ & ๖ี & $\stackrel{2}{2}$ & $\stackrel{\Xi}{\stackrel{2}{2}}$ & $\stackrel{?}{\varrho}$ & 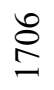 & $\stackrel{8}{2}$ & $\stackrel{\infty}{\stackrel{2}{2}}$ \\
\hline
\end{tabular}


непосредственное управление полковыми соединениями по преимуществу было передано иноземным генералам.

В этой связи, достаточно интересным является состав ряда военных советов 1708 года (участники «генеральных консилиумов» перечисляются в том порядке, в котором стоят их подписи под решениями советов). На «консилиуме» у Чашников 13 июня присутствовали Б.П. Шереметев, гр. Г.И. Головкин, кн. Г.Ф. Долгоруков, кн. А.Д. Меншиков. На «консилиум» в Могилеве 23 июня были приглашены Б.П. Шереметев, кн. А.Д. Меншиков, гр. Г.И. Головкин, кн. Г.Ф. Долгоруков, кн. А.И. Репнин, Я.В. Брюс, кн. М.М. Голицын, В. фон Швейден. 6 июля, уже после поражения под Головчино, состоялся «консилиум» в Шклове. Он был самым многочисленным: Б.П. Шереметев, кн. А.Д. Меншиков, гр. Г.И. Головкин, кн. Г.Ф. Долгоруков, бар. Г. Гольц, кн. А.И.Репнин, бар. Л.-Н. Алларт, Я.В. Брюс, бар. К.-Э. Ренне ${ }^{30}$. Как видим, помимо лиц, носивших генеральские чины, на советах лета 1708 г. в ранге «министров» неизменно присутствовали гр. Г.И. Головкин и кн. Г.Ф. Долгоруков. Военный историк А.З. Мышлаевский справедливо замечает, что смешанный состав «консилиумов», включавший в себя как русских, так и иностранцев, позволял совместить две сильные стороны российского командования этого периода. Иноземцы обладали боевым опытом и знанием теоретических основ военного дела.Наиболееталантливыепредставители русскогогенералитета, получившие в первые годы Северной войны практические навыки управления армейскими соединениями, гораздо лучше иноземцев представляли тактику неприятеля и особенности театра военных действий. Кроме того, военные советы помогали держать под контролем генералов-иностранцев, к которым Петр I относился с определенным недоверием ${ }^{31}$. Как писал в 1710 г. секретарь австрийского посольства в Москве О.-А. Плейер, важнейшие решения по военным вопросам принимались государем и лицами, входившими в его ближайшее окружение: кн. А.Д. Меншиковым, гр. Б.П. Шереметевым, Ф.М. Апраксиным, Н.М. Зотовым, гр. Г.И. Головкиным, бар. П.П. Шафировым ${ }^{32}$. Несомненно, что приведенный Плейером список неполон, а упоминаемый им Тайный военный совет не существовал как постоянное государственное учреждение. Тем не менее, очевидно, что несмотря на их многочисленность, опыт и высокую квалификацию, иностранные генералы играли в дополтавской российской армии второстепенные роли: полевых командиров и советников по сугубо военным вопросам.

В 1708 году состав российского генералитета выглядел следующим образом. В чине генерал-фельдмаршала находились Б.П. Шереметев и бар. Г. Гольц

30. Северная война на Ингерманландском и Финляндском театрах..., с. 41-45. У А.З. Мышлаевского генерал-майор Вилим фон Швейден, участвовавший в совете 23 июня, ошибочно назван фон Твейденом. В перечне подписей под решением совета от 6 июля одна фамилия (генерал-поручика от инфантерии) написана неразборчиво.

31. Северная война на Ингерманландском и Финляндском театрах ..., с. XIII-XVII.

32. О.-А. Плейер, «О нынешнем состоянии государственного управления в Московии в 1710 году», Лавры Полтавы, М., 2001, с. 412-413. 
(1 усский, 1 иноземец). Вторую ступень военной иерархии занимали генераланшефы бар. Л.-Н. Алларт, кн. А.Д. Меншиков, кн. А.И. Репнин (2 русских, 1 иноземец). Генерал-поручиками были Р.-Х. Боур, Я.В. Брюс, А.-Ф. Гейн, И.-Х. Гейнске, кн. Ф. Гессен-Дармштадтский, кн. М.М. Голицын, бар. П. Дальбон, Г. Пфлуг, бар. К.-Э. Ренне, С. Ренцель, И.И. Чамберс (1 русский, 10 иноземцев). Чин генерал-майора носили гр. А. Беллеарди, Ф.И. Беллинг, Бем, Р.В. Брюс, Н.Г. Верден, кн. Г.С. Волконский, И.Я. Гинтер, А.А. Гордон, А.А. Гулиц, А.М. Дедют, Н.Ю. Ифлант, Б.С. Корсак, бар. И.-Л. Микуш, бар. Ф.-Г. Ностиц, М.М. Полман, В.И. Швейден, гр. О.-Р. Шомбург, Штольц. Генерал-квартирмейстером генерал-майорского ранга был бар. Ф.-Р. Гольц (т.е. 2 русских, 17 иноземцев). Чины бригадира, полковника артиллерии и подполковника гвардии носили 6 русских (С.В. Айгустов, кн. А.И. Волконский ${ }^{33}$, А.М. Дмитриев-Мамонов, Я.В. Полонский, Ф.Г. Чекин, Ф.В. Шидловский) и 10 иноземцев (Ф.Н. Балк, бар. И.Ю. Бутлер, И.-Б. Вейсбах, А.А. Гешев, М.Б. Кирхен, Леметр де Со, М.-Г. Миленфельзен, Ф.И. Фастман, Т.Т. Фразер, гр. Г.-Ф. Фриз).

По нашим подсчетам, из 39 иноземцев более четверти (11 человек) были «старовыезжими»: Ф.Н. Балк, Р.В и Я.В. Брюсы, бар. И.Ю. Бутлер, Н.Г. Верден, А.А. Гордон, А.А. Гулиц, А.М. Дедют, М.Б. Кирхен, М.М. Полман, И.И. Чамберс. Остальные (т.е. более двух третей) были приняты на службу в период Северной войны. Из них (по неполным данным) выходцами из Германии были 11 человек (бар. Л.-Н. Алларт, Бем, Р.-Х. Боур, И.-Х. Гейнске, кн. Ф. Гессен-Дармштадтский, А.А. Гешев, И.Я. Гинтер, бар. Г. Гольц, бар. Ф.-Р. Гольц, Г. Пфлуг, гр. О.-Р. Шомбург), из Прибалтики - 1 (бар. К.-Э. Ренне), Австрии - 1 (И.-Б. Вейсбах), Дании и Норвегии - 1 (бар. Ф.-Г. Ностиц), Италии - 1 (гр. А. Беллеарди), Франции - 1 (Леметр де Со). Среди русских в генеральских рангах находились только 12 человек.

Кадровая политика 1702-1708 гг,, реорганизация вооруженных сил и накопленный боевой опыт позволили российским войскам совершить перелом в ходе Северной войны. Были одержаны победы при Лесной (1708 г.) и под Полтавой (1709 г.). В 1710 г., после взятия Выборга, Эльбинга, Риги, Дюнамюнде, Пернова, Аренсбурга (на о. Эзель), Кексгольма и Ревеля под контролем российских войск оказалась Эстляндия и Лифляндия.

С 1709 г. в эволюции высшего командного состава армии начинается третий этап. С этого момента мы обнаруживаем четко выраженную тенденцию к уменьшению численности иноземцев в составе генералитета. На рубеже 1711-

33. В комментариях к «Письмам и бумагам Петра Великого» Григорий Семенович и Александр Иванович Волконские ошибочно названы отцом и сыном, а у А.И. Волконского неверно указано отчество (ПиБП, т. 9, с. 566-567). Подобные неточности содержатся и в новых публикациях (Областные правители России, 1719-1739 г2., с. 254; П. А. Кротов, Битва при Полтаве, СПб., 2009, с. 50). Между тем, отцом А.И. Волконского был стольник Иван Семенович, а отцом Г.С. Волконского - стольник Семен Романович (Г. А. Власьев, указ. соч., т. 1, ч. 3, с. 343, 359, 360, 377). С именем-отчеством Александр Иванович Волконский не раз упоминается в сенатском делопроизводстве (Доклады $u$ приговоры ..., т. 2, кн. 2, с. 106; т. 4, кн. 1, с. 443 и др.). 
1712 гг. общее соотношение русских и иноземцев выровнялось. Впоследствии снижение доли иноземцев в генералитете продолжилось, и к 1724-1725 гг. в чинах первых пяти классов Табели о рангах насчитывалось $36 \%$ иноземцев и $64 \%$ русских (см. табл. 3 ).

Замена иностранного генералитета русским осуществлялась постепенно. Наиболее заметна она была среди младших чинов - бригадиров и генералмайоров. Здесь сказались как карьерный рост русских офицеров, получавших повышение из полковничьих рангов, так и отставка иноземцев после неудачного Прутского похода 1711 года и завершения военных действий на турецком направлении. Подчеркнем, что именно на рубеже 1711-12 гг. произошло резкое снижение числа иноземцев в составе генералитета (с 40 до 29 человек). Это было прямым следствием роста численности русских генералов в предшествующий период. В 1708-11 гг. их количество увеличилось с 12 до 32 человек, т.е. в 2,7 раза за 4 года. В дальнейшем столь резких скачков в численности генералитета не наблюдалось.

Укрепление позиций генералов русского происхождения повлекло за собой изменение кадровой политики в сухопутной армии. Так, весьма примечательна резолюция Петра I, данная в 1711 году в ответ на просьбу ряда иностранных генералов о повышении жалования: «Ежели настоящим жалованьем довольствоватца не будут, дать апшит (отставку.- Ч.С.). А сказать, что ежели всем платить, то малионом не оплотить» ${ }^{34}$. В том же году штатами кавалерийских и пехотных полков была установлена общая пропорция офицеров - 2/3 русских и 1/3 иноземных. Сократилось количество офицеров, получавших повышенный иноземческий оклад ${ }^{35}$. Вследствие этого, к концу Северной войны в российской армии осталось только 12,6\% офицеров-иноземцев. Однако по мере повышения ранга их доля возрастала. Так, если среди штаб-офицеров иноземцев было около трети, то среди полковников - почти половина ${ }^{36}$.

В бригадирском ранге русские начали преобладать уже с 1711 г., а к 17241725 гг. их доля достигла 76-79\%. В 1724 году в чине бригадира числилось 19 русских (кн. И.Ф. Борятинский, С.Л. Вельяминов, П.Л. Воейков, П.С. Глебовский, В.Н. Зотов, И.П. и П.В. Измайловы, В.Д. Корчмин, В.Я. Левашев, М.И. Леонтьев, И.М. Лихарев, Г.В. Норов, И.В. Панин, В.И. Порошин, С.И. Сукин, И.А. Фамендин, Я.С. Шамордин, В.П. Шереметев, И.М. Шувалов) и 6 иноземцев (А. Ветерани, М.М. Витвер, А.М. Девиер, Т.И. Трейден, Ю.И. Фаминцын, Л.Л. Шток). Из иноземцев трое (Т.И. Трейден, Ю.И. Фаминцын, Л.Л. Шток) были «старовыезжими».

Среди генерал-майоров численность русских росла более медленно. Рубеж в 50\% был преодолен в 1712 г, а к концу петровского правления доля русских генерал-майоров составила 58-61\%. В 1724 г. насчитывалось 14

34. ПиБП, т. 11, вып. 2, с. 48-49.

35. ПСЗ-I, т. IV, № 2319, с. 590-627; ПиБП, т. 12, вып. 1, с. 286.

36. М. Д. Рабинович, «Социальное происхождение...», с. 154, 157. 


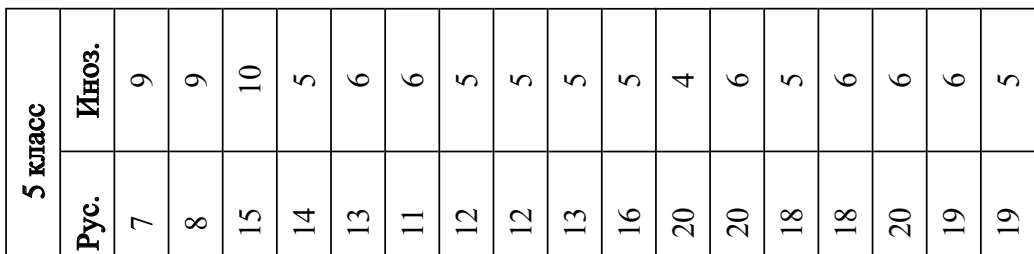

象 索

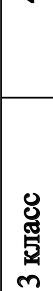

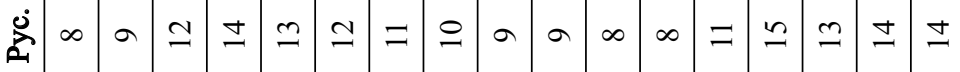

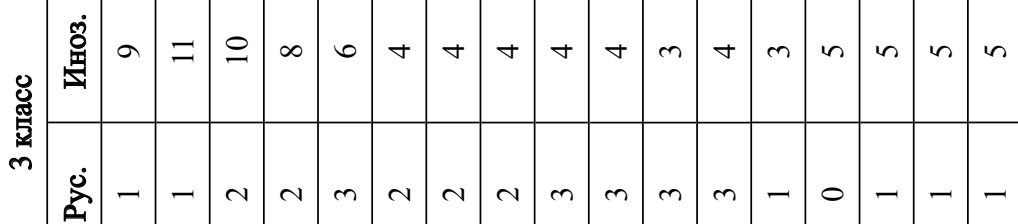

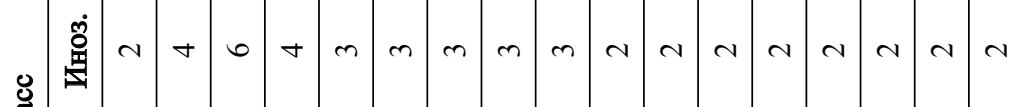
离

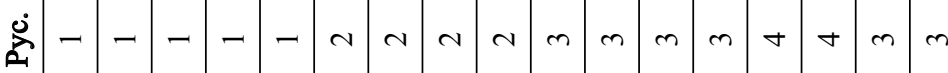

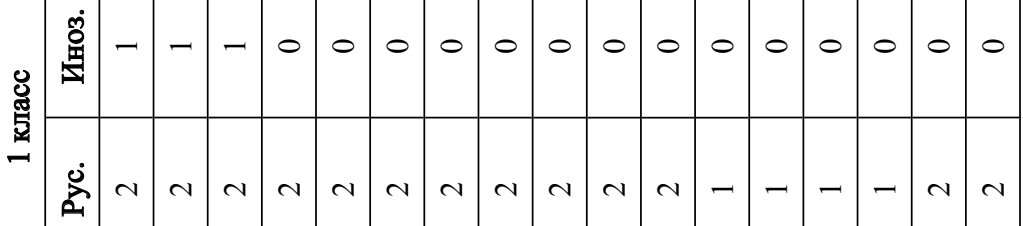

预

崖

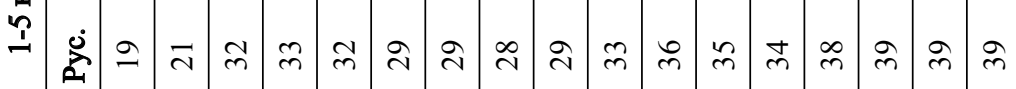

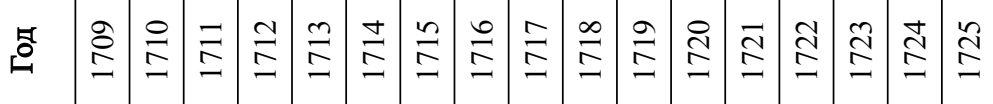


русских генерал-майоров (И.Л. Воейков, М.Я. Волков, кн. А.И. Волконский, И.М. Головин, И.И. Дмитриев-Мамонов, Г.С. Кропотов, кн. Б.И. Куракин, А.И. Румянцев, С.А. Салтыков, кн. Ю.Ю. Трубецкой, А.И. Ушаков, Ф.Г. Чекин, Г.П. Чернышев, кн. Г.Д. Юсупов) и 9 иноземцев (Ф.Н. Балк, В.И. Геннин, И.Я. Гинтер, В.В. фон Дельден, И.Я. Дюпре, А. де Кулон, П.Б. Лефорт, Х.-Ф. фон дер Ропп, Х. Урбанович). К категории «старовыезжих иноземцев» можно отнести троих: Ф.Н. Балка, В.В. фон Дельдена, П.Б. Лефорта.

Ранг генерал-лейтенанта существенно выделяется из общей картины эволюции российского генералитета. Как и ранее, на протяжении 17091725 гг. в этом чине неизменно преобладали иноземцы (исключением был только 1719 г., когда численность русских и иноземцев сравнялась). С 1709 до 1719 г. доля иноземцев постоянно снижалась, что совпадало с общими тенденциями развития генералитета. Однако с 1719 по 1725 г. их удельный вес вновь стал расти. В итоге, к 1724-1725 гг. пятеро генерал-лейтенантов являлись иноземцами: Г.-И. Бон (Германия), И.-Б. фон Вейсбах (Богемия), П.П. Ласси (Ирландия), Б.-Х. фон Миних (Ольденбург), П.И. Ягужинский (Польша) и только один был русским: М.А. Матюшкин.

Среди полных генералов в 1709-1717 гг. преобладали иноземцы, а в 17181725 гг. - русские. Наибольшее число иноземцев в этом ранге отмечается в 1711 году (6 из 7 человек, т.е. 86\%): бар. Л.-Н. Алларт, Я.В. Брюс (генералфельдцейхмейстер), А.А. Вейде, бар. К.-Э. Ренне, бар. Н. Энцберг, Л.-Г. Янус д’Эберштедт. Русским был только один генерал-аншеф - кн. А.И. Репнин. С 1712 года доля иноземцев среди генерал-аншефов сокращается. К концу царствования Петра I чины второго класса Табели о рангах носили двое иноземцев (бар. Л.-Н. Алларт, гр. Я.В. Брюс) и трое русских (И.И. Бутурлин, кн. М.М. Голицын и кн. И.Ю. Трубецкой).

Высший в сухопутной армии чин генерал-фельдмаршала после отставки в 1711 г. бар. Генриха Гольца носили только русские: гр. Б.П. Шереметев (с 1701 г.), кн. А.Д. Меншиков (с 1709 г.) и кн. А.Н. Репнин (с 1724 г.).

В таблице 4 представлены данные о карьерном росте российского генералитета в течение первой четверти XVIII столетия.

Как видим, в изучаемый период, повышение по службе получило $38 \%$ генералитета (65 человек из 172). Подавляющее число из них (85\%) были награждены более высоким рангом только один раз, и лишь $12 \%$ - дважды (Р.Х. Боур, гр. Я.В. Брюс, И.И. Бутурлин, И.-Б. Вейсбах, П.П. Ласси, М.А. Матюшкин, бар. К.-Э. Ренне, кн. И.Ю. Трубецкой). Наивысшего карьерного успеха добились аристократ кн. М.М. Голицын и худородный кн. А.Д. Меншиков: они получали повышение трижды. Всего нами учтено 77 случаев пожалования чинов: 20 за период с 1700 по 1708 г. (26\%) и 57 - в 1709-1725 гг. (74\%). Наибольшее число пожалований нового ранга относится к переломному на сухопутном театре военных действий году Полтавской битвы. В 1709 г. зафиксировано 11 случаев награждения новым генеральским чином, т.е. $14 \%$ от общего числа повышений. Обращает на себя внимание то, что в дополтавский период генералы-иноземцы не только преобладали в 


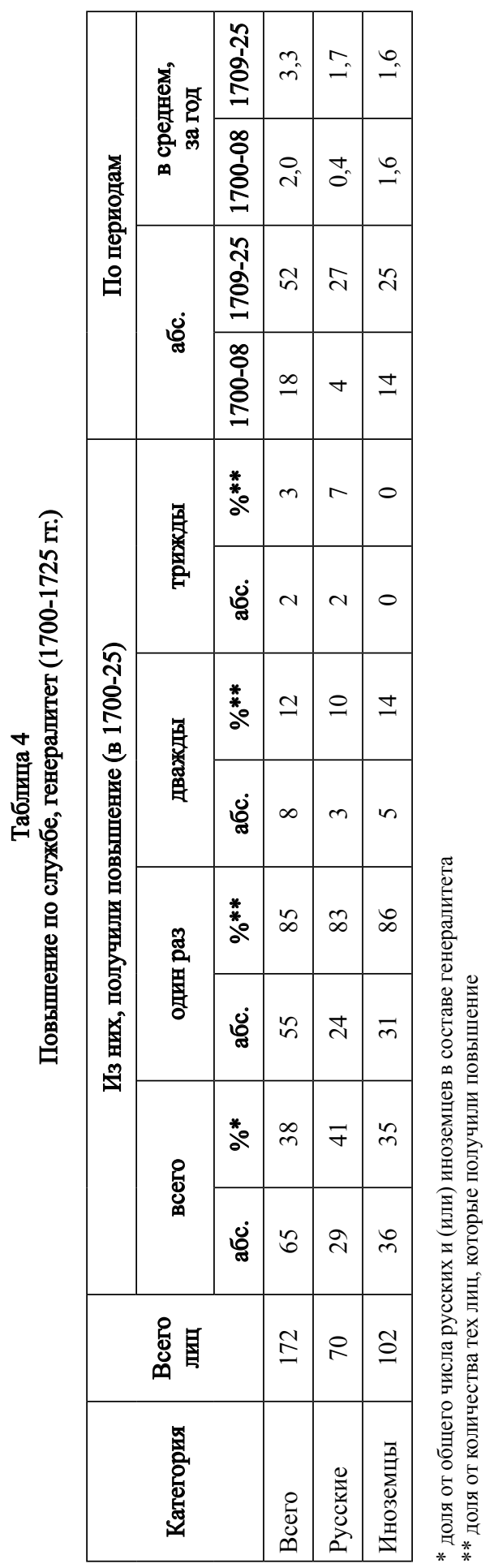


составе генералитета (см. табл. 2), но и имели существенное преимущество при чинопроизводстве. Так, за 1700-1708 гг. из 18 человек, заслуживших новый ранг, 14 являлись иноземцами и только четверо - русскими. В дальнейшем положение выровнялось за счет более интенсивного роста в чинах генералитета русского происхождения.

Как мы уже отмечали выше, данные представленные в таблицах 2-4, относятся к российскому генералитету в целом, включая лиц, служивших в гарнизонных частях, а также в управленческих структурах военного и гражданского профиля. Если из общего числа российских генералов выделить лиц, находившихся при армии и участвовавших в боевых действиях, то мы увидим очень близкие результаты. В частности, в начале 1713 года при полевой армии насчитывалось 35 представителей генералитета, из них 18 русских (51\%) и 17 иноземцев $(49 \%)^{37}$. По общим же данным, в это время из 59 генералов (см. табл. 3) было 32 русских (54\%) и 27 иноземцев (46\%). Если сравнить показатели на 1723 год, то соотношение будет таким: при полевой армии - 67\% русских и $33 \%$ иноземцев, а по всему генералитету - соответственно, 65\% и $35 \%{ }^{38}$. Таким образом, можно сделать вывод, что российский генералитет в целом и та его часть, которая служила в действующей армии, развивались согласно единой тенденции. Год Полтавской битвы стал переломным не только в ходе Северной войны, но и в кадровой политике правительства по отношению к генералитету. Вместе с тем, замена иностранцев русскими генералами носила постепенный характер и в первую очередь затрагивала младшие чины (бригадиров и генерал-майоров).

$$
* * *
$$

В отличие от сухопутной армии, российский флот имел очень короткую историю существования. Морские чины появились в России только в конце XVII столетия. Общая структура флотских чинов, сложившаяся за время петровского правления, была закреплена Морским уставом 1720 г. и Табелью о рангах 1722 г. ${ }^{39} \mathrm{~K}$ первому классу Табели относился чин генерал-адмирала, ко второму - адмиралы, в третьем состояли вице-адмиралы и морской генерал-кригс-комиссар, в четвертом - контр-адмиралы (шаутбенахты)

37. По данным ведомости о жаловании генералитету от 29 января 1713 г. Среди лиц, находившихся при полевой армии, ошибочно указан генерал-майор от кавалерии А.А. Гешев, ушедший в отставку еще в декабре 1712 г. Из морских чинов, числившихся при сухопутной армии, упоминается генерал-адмирал гр. Ф.М. Апраксин. - РГАДА, ф. 248, оп. 2, кн. 21, л. 477-482. См. также: Доклады и приговоры ..., т. 3, кн. 1, с. 17-24.

38. Отметим, что генералитет, привлекавшийся правительством в 1723 г. к исполнению гражданских обязанностей, был на 76\% русским. Генералитет, занятый в военных структурах того времени (армия, гвардия, коменданты гарнизонов, руководство и члены Военной коллегии, а также подчиненных ей учреждений), состоял из русских только на $58 \%$.

39. ПСЗ-I, т. VI, № 3485, с. 2-116, № 3890, с. 486-493; т. XLIV, ч. 1, Книга штатов, отдел. II, с. 4-6. О развитии морских чинов см.: OMC, ч. 1, с. IX-XXXVIII. 
и обер-цейхмейстер, в пятом - капитан-командоры, обер-сарвайер от корабельного строения, обер-штер-кригс-комиссар флота и цейхмейстер. Чин обер-экипажмейстера (по данным Морских штатов 1732 г.) также относился к пятому классу ${ }^{40}$. Генерал-адмирал, адмиралы, вице-адмиралы и контрадмиралы (шаутбенахты) именовались флагманами ${ }^{41}$.

Изначально, высшие флотские чины являлись номинальными, а носили их люди далекие от морского дела. Так, в 1692-94 гг. в чине адмирала упоминается комнатный стольник князь-кесарь Ф.Ю. Ромодановский, вицеадмирала - комнатный стольник И.И. Бутурлин, контр-адмирала - генерал П.И. Гордон. Во время второго Азовского похода (1696 г.) адмиралом был генерал Ф.Я. Лефорт, вице-адмиралом - венецианец Ю.С. Лима (в 1702 г. уже состоял в чине армейского полковника ${ }^{42}$ ), контр-адмиралом (шаутбенахтом) француз Б.Е. де Лозьер ${ }^{43}$. Перед началом Северной войны состав флагманов российского флота был таким. С 1699 г. чин адмирала носил ближний боярин Федор Алексеевич Головин. Вице-адмиралом с 1698 г. являлся Корнелий Иванович Крюйс, уроженец Норвегии, нанятый на русскую службу из голландского флота. Тогда же в чине шаутбенахта начал службу голландец Ян ван Рез. Из этого перечня только двое последних были опытными моряками.

Pис. 2

\section{Соотношение русских и иностранцев в составе высшего командования флота в $1700-1725$ гт.}

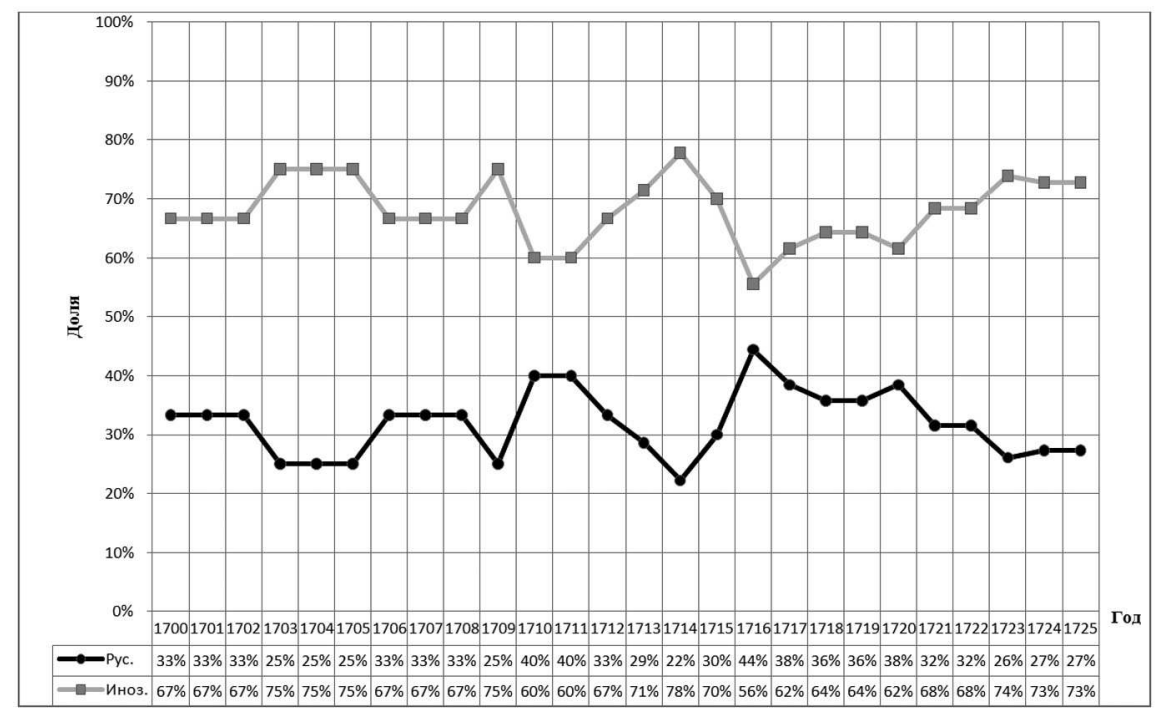

40. ПC3-I, т. XLIV, ч. 1, Книга штатов, отдел. II, с. 16, 26.

41. ПС3-I, т. XLIV, ч. 1, Книга штатов, отдел. II, с. 5, прим. 2.

42. Гистория..., вып. 1, с. 90, 218.

43. $O M C$, ч. 1 , c. IX-X. 
Эволюция состава высшего морского командования существенно отличается от процессов, происходивших в сухопутной армии. Среди руководства российского флота на всем протяжении первой четверти XVIII столетия преобладали иностранцы (см. рис. 2). Тем не менее, наивысшие посты на флоте занимали русские. До 1708 г. старшим морским чином был ранг адмирала, а с 1708 г. - генерал-адмирала. В 1699-1706 гг. чин адмирала носил гр. Ф.А. Головин (ум. в 1706 г.), а после его смерти, с февраля 1707 г. адмиралтейц (глава Адмиралтейского приказа) Ф.М. Апраксин. В 1708 г. он был пожалован в генерал-адмиралы и находился в этом ранге вплоть до своей кончины в 1728 г.

Чин адмирала оставался вакантным с 1708 по 1721 г., а по случаю заключения Ништадтского мира этим рангом был пожалован К.И. Крюйс. При образовании Адмиралтейской коллегии гр. Ф.М. Апраксин и К.И. Крюйс получили посты президента и вице-президента, соответственно.

В чине вице-адмирала вплоть до 1721 г. служил только К.И. Крюйс, а в год окончания Северной войны этого чина удостоились пятеро: швед Д. Вильстер, шотландец Т. Гордон, серб М.Х. Змаевич, датчанин П.И. Сиверс и кн. А.Д. Меншиков. Фаворит государя являлся единственным русским вицеадмиралом (исключая самого царя ${ }^{44}$ ) за все правление Петра I.

Чин контр-адмирала (шаутбенахта) при Петре I носили 14 человек: голландец Я. ван Рез (1698-1705), уроженец Далмации гр. И.Ф. Боцис (1703-14), голландец С. Трезель (1714-15), кн. А.Д. Меншиков (1716-21), англичанин Г. Паддон (1717-18), голландец В. Шелтинг (1717-18), шотландец Т. Гордон (1719-21), серб М.Х. Змаевич (1719-21), датчанин П.И. Сиверс (1719-21), голландец Я. Фангофт (1721-26), англичанин Т. Сандерс (1721-27), Н.А. Сенявин (1721-27), шотландец лорд К.-С. Дуффус (1723-32). В должности обер-цейхмейстера (высший чин морской артиллерии) контр-адмиральского ранга служил швед Х.Г. Отто (1721-25). Как видим, русских в этом списке только двое: кн. А.Д. Меншиков и Н.А. Сенявин. В конце правления Петра I среди контр-адмиралов было $80 \%$ иностранцев.

Согласно данным Ф.Ф. Веселаго, чин капитан-командора появляется на русском флоте с 1707 г., однако сам Петр I носил его с 1706 г. ${ }^{45}$ Помимо государя в этом ранге в период до 1725 г. находилось в общей сложности 26 лиц: англичанин Я. Бекман (1709-11), кн. А.Д. Меншиков (1710-16), голландцы А. Рейс (1712-14) и В. Шелтинг (1712-17), серб М.Х. Змаевич (1713-19), датчанин П.И. Сиверс (1714-19), Э. Воган (1715), шотландец Т. Гордон (1717-19), голландец Я. Фангофт (1717-21), англичанин Т. Сандерс (1718-21), француз И.А. Дежимон (1719-23), венецианец Л.М. Демьянов (Дамиани)

44. При подсчетах не учитывались чины, которые носил сам Петр I. В 1706 г. он был пожалован в капитан-командоры, в 1709 г. стал шаутбенахтом (за Полтавскую битву), в 1714 г. - вице-адмиралом (за победу при Гангуте), в 1721 г. - адмиралом (OMC, ч. 1, с. $1-8)$.

45. $O M C$, ч. 1 , c. XII, 5. 
(1719, 1722-25), Н.А. Сенявин (1719-21), норвежец П.П. Бредаль (1721-27), датчанин Х. Гагедорн (1721), голштинец М.П. Госслер (1721-27), англичанин Э. Лейн (1721-29), И.А. Сенявин (1721-25). В 1723 году чин капитан-командора получили лучшие корабельные мастера: англичане Р. Броун, Р. Козенц, О. Най и русский кораблестроитель Ф.М. Скляев. Ранг капитан-командора также имели цейхмейстер Х.Г. Отто (1715-21), обер-штер-кригс-комиссар флота Г.П. Чернышев (1715-22), обер-экипажмейстер кн. И.Б. Львов (1716-18), оберсарвайер корабельного строения И.М. Головин (1717-25). Следовательно, в ранге капитан-командора в первой четверти XVIII в. служило только 7 человек русского происхождения. Двое из них (И.М. Головин, Ф.М. Скляев) были судостроителями, а еще двое (Г.П. Чернышев, кн. И.Б. Львов) занимали административные должности в Адмиралтействе. Отметим, что Чернышев одновременно был генерал-майором сухопутной армии. К 1724-25 гг. в чинах пятого класса Табели о рангах на морской службе находилось 70\% иностранцев и $30 \%$ русских.

Таким образом, становление российского военного флота при Петре I прошло при полном доминировании иностранных моряков в составе высшего командования (см. табл. 5). До флагманских чинов (от контр-адмирала и старше) удалось дослужиться только двоим русским: кн. А.Д. Меншикову и Н.А. Сенявину. Несмотря на стремление Петра I подготовить национальные кадры для российского флота, каких-либо кардинальных изменений в составе высшего морского командования к концу его правления так и не произошло. Самые высокие должности на флоте были изначально отданы русским (Ф.А. Головин, затем Ф.М. Апраксин). Однако это объяснялось не реальным опытом и заслугами в морском деле, а традицией и нежеланием Петра I передавать верховное командование в руки иностранцев.

Данные о карьерном росте старших морских чинов первой четверти XVIII века представлены в таблице 6.

Повышение в ранге здесь получил каждый третий капитан-командор или флагман. Это, в целом, совпадает с данными по армейскому генералитету (см. табл. 4). Однако подсчеты свидетельствуют, что повторное повышение на флоте было более частым явлением, нежели в сухопутной армии. Так, среди высших морских чинов дважды повышались в ранге $36 \%$ лиц (Т. Гордон, М.Х. Змаевич, кн. А.Д. Меншиков, П.И. Сиверс). В составе генералитета таковых было только 12\%, а с учетом двух человек, удостоившихся повышения трижды - 15\%. Более активный карьерный рост на флоте видимо объяснялся тем, что этот вид вооруженных сил находился при Петре I на начальной стадии своего развития. Из 15 случаев повышения в чине лишь один относится к 1700-1708 гг. (7\%), остальные 14 (93\%) - к 1709-1725 гг. Перелом в ходе военных действий на море наступил позднее, чем на сухопутном театре. Поэтому вполне предсказуемо, что пик повышений по служебной лестнице среди флотского командования пришелся на самый конец Северной войны. Так, в 1719 г. новый флагманский чин получили трое (20\%), а в год заключения Ништадтского мира (1721 г.) - 9 человек (60\%). 
Таблица 5

Численность русских и иностранщев в высших флотских чинах, 1700-1725 гт.

\begin{tabular}{|c|c|c|c|c|c|c|c|c|c|c|c|c|}
\hline \multirow{2}{*}{ Год } & \multicolumn{2}{|c|}{ 1-5 классы } & \multicolumn{2}{|c|}{1 класс } & \multicolumn{2}{|c|}{2 класс } & \multicolumn{2}{|c|}{3 класс } & \multicolumn{2}{|c|}{4 класс } & \multicolumn{2}{|c|}{5 класс } \\
\hline & Pyc. & Иноз. & Pyc. & Иноз. & Pyc. & Иноз. & Pyc. & Иноз. & Pyc. & Иноз. & Pyc. & Иноз. \\
\hline 1700 & 1 & 2 & 0 & 0 & 1 & 0 & 0 & 1 & 0 & 1 & 0 & 0 \\
\hline 1701 & 1 & 2 & 0 & 0 & 1 & 0 & 0 & 1 & 0 & 1 & 0 & 0 \\
\hline 1702 & 1 & 2 & 0 & 0 & 1 & 0 & 0 & 1 & 0 & 1 & 0 & 0 \\
\hline 1703 & 1 & 3 & 0 & 0 & 1 & 0 & 0 & 1 & 0 & 2 & 0 & 0 \\
\hline 1704 & 1 & 3 & 0 & 0 & 1 & 0 & 0 & 1 & 0 & 2 & 0 & 0 \\
\hline 1705 & 1 & 3 & 0 & 0 & 1 & 0 & 0 & 1 & 0 & 2 & 0 & 0 \\
\hline 1706 & 1 & 2 & 0 & 0 & 1 & 0 & 0 & 1 & 0 & 1 & 0 & 0 \\
\hline 1707 & 1 & 2 & 0 & 0 & 1 & 0 & 0 & 1 & 0 & 1 & 0 & 0 \\
\hline 1708 & 1 & 2 & 1 & 0 & 0 & 0 & 0 & 1 & 0 & 1 & 0 & 0 \\
\hline 1709 & 1 & 3 & 1 & 0 & 0 & 0 & 0 & 1 & 0 & 1 & 0 & 1 \\
\hline 1710 & 2 & 3 & 1 & 0 & 0 & 0 & 0 & 1 & 0 & 1 & 1 & 1 \\
\hline 1711 & 2 & 3 & 1 & 0 & 0 & 0 & 0 & 1 & 0 & 1 & 1 & 1 \\
\hline 1712 & 2 & 4 & 1 & 0 & 0 & 0 & 0 & 1 & 0 & 1 & 1 & 2 \\
\hline 1713 & 2 & 5 & 1 & 0 & 0 & 0 & 0 & 1 & 0 & 1 & 1 & 3 \\
\hline 1714 & 2 & 7 & 1 & 0 & 0 & 0 & 0 & 1 & 0 & 2 & 1 & 4 \\
\hline 1715 & 3 & 7 & 1 & 0 & 0 & 0 & 0 & 1 & 0 & 1 & 2 & 5 \\
\hline 1716 & 4 & 5 & 1 & 0 & 0 & 0 & 0 & 1 & 1 & 0 & 2 & 4 \\
\hline 1717 & 5 & 8 & 1 & 0 & 0 & 0 & 0 & 1 & 1 & 2 & 3 & 5 \\
\hline 1718 & 5 & 9 & 1 & 0 & 0 & 0 & 0 & 1 & 1 & 2 & 3 & 6 \\
\hline 1719 & 5 & 9 & 1 & 0 & 0 & 0 & 0 & 1 & 1 & 3 & 3 & 5 \\
\hline 1720 & 5 & 8 & 1 & 0 & 0 & 0 & 0 & 1 & 1 & 3 & 3 & 4 \\
\hline 1721 & 6 & 13 & 1 & 0 & 0 & 1 & 1 & 4 & 1 & 3 & 3 & 5 \\
\hline 1722 & 6 & 13 & 1 & 0 & 0 & 1 & 1 & 4 & 1 & 3 & 3 & 5 \\
\hline 1723 & 6 & 17 & 1 & 0 & 0 & 1 & 1 & 4 & 1 & 4 & 3 & 8 \\
\hline 1724 & 6 & 16 & 1 & 0 & 0 & 1 & 1 & 4 & 1 & 4 & 3 & 7 \\
\hline 1725 & 6 & 16 & 1 & 0 & 0 & 1 & 1 & 4 & 1 & 4 & 3 & 7 \\
\hline
\end{tabular}




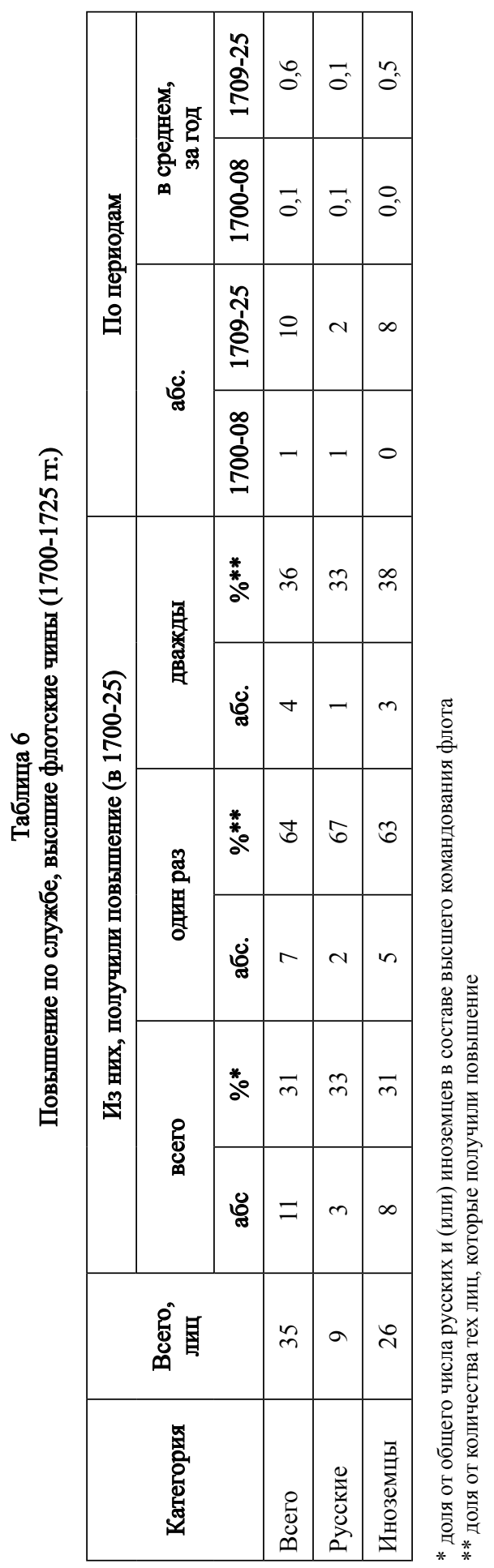


В заключение, рассмотрим вкратце происхождение иноземцев, служивших в составе высшего командования армии и флота первой четверти XVIII столетия (см. табл. 7). Как уже было отмечено, их насчитывалось 128 человек (102 - в армии, 26 - на флоте). Данные о происхождении нам известны для 99 лиц $(77 \%)$.

Таблица 7

Иноземщы в составе высшего командования армии и флота, 1700-1725 гт.

\begin{tabular}{|l|c|c|c|}
\hline \multicolumn{1}{|c|}{ Страна / регион } & $\begin{array}{c}\text { Армия и флот, } \\
\text { абс. (\%*) }\end{array}$ & $\begin{array}{c}\text { Армия, } \\
\text { aбc. (\%*) }\end{array}$ & $\begin{array}{c}\text { Флот, } \\
\text { абс. (\%*) }\end{array}$ \\
\hline Австрия & $5(5)$ & $5(7)$ & $0(0)$ \\
\hline Англия и Шотландия & $10(10)$ & $1(1)$ & $9(36)$ \\
\hline Германия & $21(21)$ & $20(27)$ & $1(4)$ \\
\hline Голландия & $7(7)$ & $2(3)$ & $5(20)$ \\
\hline Грузия и Имеретия & $1(1)$ & $1(1)$ & $0(0)$ \\
\hline Дания и Норвегия & $6(6)$ & $2(3)$ & $4(16)$ \\
\hline Ирландия & $1(1)$ & $1(1)$ & $0(0)$ \\
\hline Италия и Адриатика & $4(4)$ & $1(1)$ & $3(12)$ \\
\hline Молдавия и Валахия & $1(1)$ & $1(1)$ & $0(0)$ \\
\hline Польша & $2(2)$ & $2(3)$ & $0(0)$ \\
\hline Португалия & $1(1)$ & $1(1)$ & $0(0)$ \\
\hline Прибалтика & $7(7)$ & $7(9)$ & $0(0)$ \\
\hline Франция & $7(7)$ & $6(8)$ & $1(4)$ \\
\hline Швеция & $3(3)$ & $1(1)$ & $2(8)$ \\
\hline Россия (иноземцы старого выезда) & $23(23)$ & $23(31)$ & $0(0)$ \\
\hline $\begin{array}{l}\text { Итого, с известным } \\
\text { происхождением }\end{array}$ & $\mathbf{9 9 ( 1 0 0 )}$ & $\mathbf{7 4 ~ ( 1 0 0 )}$ & $\mathbf{2 5 ( 1 0 0 )}$ \\
\hline
\end{tabular}

* доля от числа иноземцев с известным нам происхождением (по видам службы)

Как видим, в сухопутной армии преобладали иноземцы «старого выезда», обосновавшиеся в России еще в XVII столетии (31\%), и выходцы из Германии, поступившие на службу при Петре I (27\%). В гораздо меньшем количестве в составе генералитета были представлены уроженцы прибалтийских земель (9\%), французы (8\%) и австрийцы (7\%). На флоте доминировали выходцы из стран Северной Европы с давними традициями мореплавания: Англии и Шотландии (36\%), Голландии (20\%), Дании и Норвегии (16\%), Швеции (8\%). Среди представителей юга Европы выделяются уроженцы Италии и побережья Адриатики (12\%), служившие в галерном флоте. 
Мы не располагаем полными данными о конфессиональном статусе иностранцев, занимавших высшие посты в армии и на флоте. Однако приведенные цифры позволяют утверждать, что давняя традиция приглашения на русскую службу военных из тех стран, которые подверглись активному влиянию Реформации, сохранилась и при Петре I. Число католиков среди военного руководства было незначительным.

$$
* * *
$$

Подведем основные итоги. Со времени Смоленской войны (1632-1634 гг.) влияние европейских военных стандартов стало постоянно действующим фактором в развитии вооруженных сил России. Однако степень этого влияния на протяжении последующих десятилетий была различной. Она зависела как от конкретных внешнеполитических задач, стоявших перед Москвой, так и от возможностей казны. Полки «нового строя», фактически ставшие первым шагом к военным реформам Петра I, были сформированы под руководством иноземных офицеров. Однако, производя иноземцев в высокие ранги, московское правительство XVII столетия не позволяло им играть в армии самостоятельную роль, а пожалование «московскими чинами» (стольников, дворян московских, стряпчих) было возможно только после перехода в православие ${ }^{46}$.

При всей масштабности реформ первой четверти XVIII века, кадровая политика в армии и отношение Петра I к европейским новациям (военной мысли, в частности), во многом уходили корнями в предшествующий период. Заимствование западных технологий, учреждений, военных образцов, как и ранее, носило сугубо прикладной характер. Зачастую проявлялись традиционная настороженность, подсознательное недоверие государя и подавляющего большинства московской элиты к иноземцам. Обращение к европейским достижениям в области военного дела, формирование регулярных вооруженных сил, массовый наем иностранных специалистов были вынужденными мерами, причиной которых стало поражение под Нарвой. Эти шаги позволили Петру I внести перелом в ход Северной войны. К 1708-1709 гг. доля иноземцев, занимавших высшие должности в сухопутной армии, составила 68-76\%, и именно этот командный состав привел Россию к победе под Полтавой. Непосредственным подтверждением значительного вклада генералов-иностранцев в исход полтавского сражения являлось то, что наряду с Б.П. Шереметевым, А.Д. Меншиковым, А.И. Репниным, Г.Ф. Долгоруковым, М.М. Голицыным, С.В. Айгустовым, Я.В. Полонским, Г.П. Чернышевым, различные награды за баталию получили Л.-Н. Алларт, Я.В. Брюс, С. Ренцель, К.-Э. Ренне, Р.Х. Боур, Н.Г. Верден, Бук, Бой. Трое 
из перечисленных иноземцев (Алларт, Брюс и Ренцель) были удостоены высшего российского ордена св. Андрея Первозванного ${ }^{47}$. Впоследствии, благодаря практическому опыту, накопленному в ходе Северной войны, росту в чинах русской части командного корпуса, а также целенаправленным шагам российскогоправительства(отставкарядаиностранныхгенералов, сокращение числа получателей повышенных «иноземческих» окладов, введение Штатов 1711 г. и др.), доля иноземцев стала снижаться, достигнув к 1725 году 36\% от общей численности генералитета. Эти изменения были постепенными и касались в первую очередь низших генеральских чинов (бригадиров и генерал-майоров). С другой стороны, в руководстве относительно молодого и нового для России вида вооруженных сил - военно-морского флота - на всем протяжении правления Петра І доминировали иностранцы. В 1725 г. их удельный вес составлял $73 \%$.

Северная война стала прекрасной школой и для последующих поколений российского высшего командного состава. Так, среди генералитета 1742 года 95\% русских и 59\% иноземцев начинали свою службу в петровской армии. Но несмотря на все усилия царя-реформатора по обучению национальных командных кадров, зависимость России от европейских военных специалистов оставалась очень существенной. В 1742 г. доля генераловиностранцев сохранилась на уровне конца петровского правления - 37\%. Их роль в составе действующей армии (полевая армия, гвардия, ландмилиция, артиллерия, инженерный корпус) была еще выше - 59\%. Напротив, высшие должности в центральных учреждениях военного профиля (Военной коллегии и конторе, Главном кригс-комиссариате, канцелярии Главной артиллерии и фортификации, Провиантской конторе), а также вакансии командующих гарнизонными войсками заполнялись в первую очередь русскими ${ }^{48}$.

Одним из важнейших итогов военных реформ Петра I стали изменения в структуре служилого класса. Как отметил американский историк М. По, «будет лишь незначительным преувеличением утверждать, что история социальной стратификации Московского государства - это история попыток правительства укрепить боеспособность собственной армии и мобилизовать ресурсы общества для этой цели» ${ }^{49}$. Этот тезис в полной мере применим и к первой четверти XVIII столетия. Последствия петровского этапа «военной революции» были весьма масштабными. В это время государев двор стал основным резервуаром для назначения на офицерские и генеральские должности в сухопутной армии. Необходимость модернизации военной сферы привела к снижению роли традиционной элиты в управлении ${ }^{50}$. Одновременно

47. ПиБП, т. 9, с. 287-288, 1085-1088. См. также: Гистория..., вып. 1, с. 319.

48. См.: С. В. Черников, «Генералы Елизаветы Петровны», Родина, 2009, № 2, с. 93-96.

49. M. Poe, «The Consequences...», p. 613-614.

50. См.: С. В. Черников, «Состав и эволюция российского генералитета в первой четверти XVIII века», Полтавская битва и ее международное значение. Тезисы докладов юбилейной международной научной конференции, М., 2009, с. 119-121 
возросла доля незнатного дворянства и иностранцев, занимавших высшие командные посты. Начиная с правления первых Романовых военная служба превратилась в один из основных способов повышения социального статуса. При Петре I, в условиях постоянных реформ и длительной Северной войны, значение этого фактора резко возросло. Милитаризация российского общества создавала благоприятные условия для массового вхождения генералитета в состав правящей элиты страны. На протяжении последующих десятилетий высший командный корпус сохранил те черты, которые он приобрел в петровскую эпоху: профессионализм, смешанный социальный состав, многонациональность и активное участие в государственном управлении.

Université technique d'État de Lipetsk

zserg72@gmail.com 


\section{Приложение - Список лиц, состоявших в высших чинах армии и флота в 1700-1725 гг.}

В перечень внесены все лица, имевшие сухопутные и морские чины 1-5 классов Табели о рангах, и находившиеся на действительной службе. Для каждого лица отмечено время пребывания в этих чинах (периоды отставки или плена исключены). Если крайние даты (либо одна из них) нахождения в чине остались невыясненными, это отмечается многоточием (...). Сомнения в датировке, имени, отчестве отмечаются вопросительным знаком (?) (помета относится к ближайшему слову или дате, стоящему слева от нее). Для иноземцев (они выделены курсивом) указаны национальность и (или) место рождения и написание фамилии на оригинальном языке или латиницей (если эти данные известны); также приведены наиболее распространенные в источниках варианты написания имени и фамилии кириллицей.

В перечне использованы следующие сокращения: бар. - барон, гр. - граф, кн. - князь.

Источники, на основании которых составлен список, перечислены в примечаниях к тексту статьи.

Айгустов Савва Васильевич - бригадир ...1705-1709, генерал-майор 1709$1712 \ldots$

Алларт (Галларт) (Hallart) Людвиг-Николай фон, бар. - немец (Саксония), генерал-лейтенант 1706-1707, генерал-аншеф 1707-1712, 1721-1725

Альфендель (Альбедиль) (Albedyhl) Густав-Эрнст - лифляндец, генералмайор 1710-1711, генерал-лейтенант 1711-1714...

Анненков Иван? - бригадир ...1712...

Апраксин Федор Матвеевич, гр. - адмирал 1707-1708, генерал-адмирал 17081728

Апухтин Василий Андреевич - генерал-квартирмейстер в ранге генералмайора 1711-1715

Балк Федор Николаевич - лифляндец (родился в России), бригадир 1705-1716, генерал-майор 1716-1727...

Бекман (Бекгам, Беком) (Bekham) Иван (Ян) - англичанин, капитан-командор 1709-1711

Беллеарди (Белуарди) Александр, гр. - итальянец, генерал-майор 1708$1709 . .$.

Беллинг (Беленк) Федор Иванович - генерал-майор ...1705-1709, генералпоручик 1709-1712...

Бем (Behm, Böhm) - немец, генерал-майор ...1707-1709...

Берден фон - швед, генерал-майор 1722-...

Берхгольи (von Bergholz) Вильгельм фон - немец (Голштиния), генерал-майор 1709-1710..., генерал-поручик ...1711-1714

Бирон - генерал-майор ...1705-1706 
Блумберг (Бломберг) Иван (Иоганн-Эрнст) Иванович, бар. - курляндец, полковник Преображенского полка ...-1700

Бой (Боэ) - бригадир 1709-1711

Болобанов Алексей Кузьмич - бригадир ...1714?- 1719...

Бон (Bohn) Герман-Иоганн - немец (Дания, о. Борнхольм), генерал-майор ...1711-1718, генерал-поручик 1718-1725

Боргсдорф (von Borgsdorf) Эрнст-Фридрих фон, бар. - австриец, полковник артиллерии 1696-1704?

Борятинский Иван Федорович, кн. - бригадир 1719-1725

Боур (Ваиег) Родион Христианович - немец (Голштиния), генерал-майор 1705-1706, генерал-поручик 1706-1717, генерал-аншеф 1717

Боцис Иван Федосеевич, гр. - далматинец, по др. сведениям итальянец, шаутбенахт 1703-1714

Бредаль (Bredall) Петр (Питер) Петрович - норвежец, капитан-командор 1721-1727

Броун (Brown) Ричард - англичанин, капитан-командор 1723-1733

Брюс (Вrисе) Роман Вилимович - шотландец (родился в России), генералмайор 1705-1710, генерал-поручик 1710-1720

Брюс (Вrисе) Яков Вилимович, гр. - шотландец (родился в России), генералмайор 1700-1706, генерал-лейтенант 1706-1711,генерал-фельдцейхмейстер 1711-1726

Бук - генерал-майор 1709-1713...

Бутлер (Бутерер, Бутелер) Иван Юрьевич, бар. - курляндец, бригадир 1707$1708 \ldots$

Бутурлин Иван Иванович - генерал-майор ...1700, 1710-1713, генералпоручик 1713-1721, генерал-аншеф 1721-1727

Буш Иван Алферьевич - генерал-майор ...1710-1713...

Буш Юрий Иванович - бригадир ...1711-1715...

Вейде Адам Адамович - голландец, по др. сведениям немец (родился в России), генерал-аншеф ...1700, 1711-1720

Bейсбах (Weißbach) Иоганн-Бернард фон - австриец (Богемия), бригадир 1708-1711, генерал-майор 1711-1717, генерал-лейтенант 1717-1725

Вельяминов Степан Лукич - бригадир 1721-1726

Венедигер - немец (Саксония), генерал-поручик 1705-1706

Верден Николай (Николай-Клаус) Григорьевич фон - генерал-майор 17021709, генерал-поручик 1709-1712...

Ветерани Андрей - Венгрия, бригадир ...1722-1726

Видеман (Видман) Иван? - генерал-майор ...1710-1711

Вильстер (Wilster) Даниил - швед, вице-адмирал 1721-1732

Витвер Матвей Матвеевич - полковник артиллерии 1722-1727

Воган Эдвард - капитан-командор 1715

Воейков Иван Лукич - бригадир 1716-1724, генерал-майор 1724-1726...

Воейков Петр Лукич - бригадир 1719-1726

Волков Михаил Яковлевич - бригадир 1711-1721, генерал-майор 1721-1726 
Волконский Александр Иванович, кн. - бригадир ...1707-1709, генерал-майор $1709-1725 \ldots$

Волконский Григорий Семенович, кн. - генерал-майор 1705-1713...

Востромирский (Востромицкий) Ганс-Герман - немец (Саксония?), генералмайор ...-1706

Гагарин Богдан Иванович, кн. - бригадир ...1713-1714...

Гагедорн Христофель - датчанин, капитан-командор 1721-...

Гейм (Гегейм) - бригадир ...1709...

Гейн Август-Фридрих - генерал-майор ...-1708, генерал-лейтенант 1708

Геннин (Hепnin) Вилим (Георг-Вильгельм) Иванович - немец (Нижняя Саксония, г. Ганновер), полковник артиллерии 1716-1722, генерал-майор $1722-1728$

Гейнске (Генскин) (Heinske) Иоганн-Христиан - немец (Саксония?), генералмайор 1705-1707, генерал-поручик 1707-1710...

Гессен-Дармштадтский (Дармштадт) (Hessen-Darmstadt) Фридрих, кн. (ландграф) - немец (Гессен-Дармштадт), генерал-поручик ...1707-1708

Гечен - бригадир ...1710...

Гешев (Ешев, Гешков, Эзево-Гешев) Антон Антонович - немец (Саксония), бригадир 1708, генерал-майор 1709-1712

Гинтер (Günter) Иван (Иоганн) Яковлевич - немец (г. Данциг), полковник артиллерии 1706-1708, генерал-майор 1708-1725

Глебов Федор Никитич - бригадир 1711-1713..., генерал-майор ...1715..., обер-штер-кригс-комиссар 1715-1719...

Глебовский Понкратий Сафонович - бригадир 1723-1726...

Голицын Михаил Михайлович старший, кн. - бригадир 1705-1706, генералмайор 1706-1708, генерал-поручик 1708-1714, генерал-аншеф 1714-1725

Голицын Петр Михайлович, кн. - бригадир ...1711-1716, генерал-майор 17161722

Головин Автамон Михайлович - генерал-аншеф ...1700, 1718-1720

Головин Алексей Алексеевич - бригадир ...-1709, генерал-майор 1709-1718?

Головин Иван Михайлович - бригадир ...1711-1712, генерал-майор 1712$1725 \ldots$, обер-сарвайер 1717-1725

Головин Федор Алексеевич, гр. - адмирал 1699-1706, генерал-фельдмаршал $1700-1706$

Гольи (Goltz) Генрих, бар. - немец (Бранденбург), генерал-аншеф 1707, генерал-фельдмаршал-лейтенант 1707-1711

Гольи (Goltz) Франй-Рюдигер, бар. - немец, генерал-квартирмейстер 1708$1709 \ldots$

Горбов Иван Степанович - бригадир 1706-1707, генерал-майор 1707-1708?

Гордон (Gordon) Александр Александрович - шотландец, генерал-майор 17081711

Гордон (Gordon) Томас - шотландец, по др. сведениям англичанин, капитанкомандор 1717-1719, шаутбенахт 1719-1721, вице-адмирал 1721-1727 
Госслер (Gosseler) Мартын Петрович - немец (Шлезвиг-Гольштейн, г. Альтона на Эльбе), капитан-командор 1721-1727

Гошке (Гошка) Иоганн (Яган) - голландец, полковник артиллерии ...17011706

Граге (Краге) Казимир де - австриец, полковник артиллерии 1696-1700

Гулии Андрей Андреевич - генерал-майор ...1701-1708...

Гундорф (Гондорф) - датчанин, бригадир ...1707...

Дальбон (d Albonne) Петр, бар. - генерал-поручик ...1708-1709...

Дебосо - бригадир ...1710...

Девиер (Дивиер) (de Vierra) Антон Мануйлович - еврей (Португалия), бригадир 1720-1725, генерал-майор 1725-1726...

Дедют (Де-Дьюит, Эйдут) Алексей Михайлович - француз, генерал-майор 1707-1713...

Дежимон (de Gimond) Иван (Ян) Андреевич - француз, капитан-командор 1719-1723

Дельден Вилим (Вильгельм) Вилимович фон - голландец, бригадир 1713$1714 \ldots$, генерал-майор ...1715-1726

Демьянов (Дамиани) (Damiani) Лука Михайлович - венецианец, капитанкомандор 1719, 1722-1725

Дмитриев-Мамонов Афанасий Михайлович - бригадир ...1708-1713...

Дмитриев-Мамонов Иван Ильич - бригадир 1718-1722, генерал-майор 17221726

Долгоруков Василий Владимирович, кн. - подполковник лейб-гвардии Преображенского полка 1709-1718, генерал-майор 1709-1717, генераллейтенант 1717-1718

Долгоруков Яков Федорович, кн. - генерал-комиссар 1700, генералпленипотенциар-кригс-комиссар 1711-1720

Дуффус (Duffus) Кеннет-Сатерленд, лорд - шотландец, шаутбенахт 17231732

Дюпре (Duрге) Иван Яковлевич - француз, бригадир ...-1713, генерал-майор 1713-1726

Змаевич (Змајевић, Zmajević) Матвей (Матия) Христофорович - серб (Бока Которская, г. Пераст), капитан-командор 1713-19, шаутбенахт 1719-21, вице-адмирал 1721-27

Зотов Василий Никитич - бригадир 1711-1725

Иваницкий (Эваницкий) Карл-Густав Иванович - бригадир ...1710-1720...

Измайлов Иван Петрович - бригадир 1716-1726

Измайлов Петр Васильевич - бригадир 1717-1728

Имеретинский Александр Арчилович, ияаревич - имеретинец (Грузия, Имеретия), генерал-фельдцейхмейстер 1699-1700

Ифлант (Инфлант) Николай Юсторович - генерал-майор ... 1708-1709

Кантакузин Фома Матвеевич, гр. - Молдавия и Валахия, генерал-майор 1711-1722 
Келин (Келен, Келлинг) Алексей Степанович - немец, генерал-майор 1709$1713 \ldots-1715 ?$

Кирхен (Kircken) Марк Богданович фон - немец (Пруссия), подполковник лейб-гвардии Преображенского полка 1706-1709, генерал-майор ...17091710

Козени (Козенс) Ричард - англичанин, капитан-командор 1723-1735

Кольцов-Мосальский Иван Михайлович, кн. - генерал-аншеф ... 1702-1707

Корренберг (Корнберк) фон - немец, генерал-лейтенант 1703

Корсак Богдан Семенович - смоленский шляхтич, генерал-майор ...1702$1714 \ldots$

Корчмин Василий Дмитриевич - бригадир ...1722-1726

Крои (де Круа, Кроа, Крой) (von Кгӧу) Карл-Евгений, гериог - голландец, генерал-фельдмаршал 1700

Кропотов Гавриил Семенович - бригадир 1709-1719, генерал-майор 17191728

Крюйс (Сruуs) Корнелий Иванович - норвежец (г. Ставангер), вице-адмирал 1698-1721, адмирал 1721-1727

Кулон (de Coulon) Алферий де - француз, генерал-майор 1721-1727

Куракин Борис Иванович, кн. - генерал-майор 1712-1725...

Ламбер де Герэн (Lambert de Guerin) Жозеф-Гаспар - француз, инженергенерал 1701-1706

Ламберти, гр. - бригадир...1711

Ласcи (Лесcu) (Lacy) Петр Петрович - ирландец (Лимерик), бригадир 17111712, генерал-майор 1712-1720, генерал-лейтенант 1720-1725

Левашев Василий Яковлевич - бригадир 1719-1725

Лейн (Lane) Эдвард - англичанин, капитан-командор 1721-1729

Леметр де Co (Lemestre de Sault) - француз, полковник артиллерии ...1707$1709 \ldots$

Леонтьев Михаил Иванович - бригадир 1720-1726

Лeфopm (Lefort, le Fort) Петр Богданович - швейцарец, бригадир 1712-1721, генерал-майор 1721-1728

Лихарев Иван Михайлович - бригадир 1721 (1722?)- 1726

Львов Иван Борисович, кн. - обер-экипажмейстер 1716-1718...

Матюшкин Михаил Афанасьевич - бригадир 1715-1716, генерал-майор 17161723, генерал-лейтенант 1723-1727

Меншиков Александр Данилович, кн. - генерал-майор 1704, генерал-поручик 1704-1705, генерал-аншеф 1705-1709, генерал-фельдмаршал 1709-1727, капитан-командор 1710-1716, шаутбенахт 1716-1721, вице-адмирал 1721$1725 \ldots$

Микуш Иоганн-Людвиг, бар. - генерал-майор ...1708-1709

Миленфельзен (Миленфельз) Максимилиан-Генрих фон - бригадир ...-1708

Миних (von Münnich) Бурхард-Христофор фон - немец (Ольденбург), генералмайор 1721-1722, генерал-лейтенант 1722-1727 
Моро де Бразе (Могеаи de Brasey) Жан-Николя, гр. Лионский (Сотtе de Lion en Beauce) - француз, бригадир 1711

Най Oсип - англичанин, капитан-командор 1723-1737

Наумов Федор Васильевич - обер-штер-кригс-комиссар 1715-1718

Hеттельгорст (von Nettelhorst) фон - немец, бригадир ...1706?...

Новосильцов Василий Яковлевич - обер-штер-кригс-комиссар 1718-1720...

Норов Гаврила Васильевич - бригадир 1723-1725...

Ностии (Ностес) Фридрих-Гартвиг, бар. - датчанин, генерал-майор 17061710, генерал-поручик 1710-1711

Огильви (von Ogilvy) Георг-Бенедикт, бар. -шотландец, генерал-фельдмаршаллейтенант 1704-1706

Осипов (Есипов) Федор Осипович - бригадир ...1711-1714...

Остен (von der Osten) фон дер - генерал-лейтенант ...1710-11

Oттоо (Ottoj) Христиан Григорьевич - швед, цейхмейстер 1715-1721, оберцейхмейстер 1721-1725

Паддон (Paddon) Георгий - англичанин, шаутбенахт 1717-1718

Панин Иван Васильевич - обер-штер-кригс-комиссар 1720-1726

Паткуль (von Patkull) Иоганн-Рейнгольд фон - лифляндец, генерал-майор ...1703-1704, генерал-поручик 1704-1705 (с учетом ареста в 1705).

Полман (Болман) Мартын Мартынович - генерал-майор ...1706-1713...

Полонский Яков Васильевич - бригадир ...1708-1709, генерал-майор 17091713

Порошин Василий Иванович - бригадир ...1711-1725

Пфлуг (Флюк) (Pflugk) Гебгард - немец, генерал-майор 1705-1706..., генераллейтенант ...1708-1713...

Рез (Pec) (van Reez) Ян ван - голландец, шаутбенахт 1698-1705

Peŭc (Rees) Авраам - голландец, капитан-командор 1712-1714

Ремхин (Ремкинг) - бригадир ...1710-1711

Ренне (Рен) (Rӧnпе) Карл-Эвальд, бар. - курляндец, генерал-майор 1704-1705, генерал-поручик 1705-1709, генерал-аншеф 1709-1716

Ренцель (Ранцель) (Rentzell) Самуил - генерал-майор 1707-1708, генераллейтенант 1708-1710

Репнин Аникита Иванович, кн. - генерал-аншеф ...1698-1724, генералфельдмаршал 1724-1726

Ригеман (Ригимон) Христофор-Генрих - генерал-майор ...1700-1702...

Puдер (Pbldер) (Ridder) Иван Иванович - бригадир ...1705..., генерал-майор ...1705...

Розен (von Rosen) Георг-Густав фон, бар. - лифляндец, генерал-поручик $1703-1706 \ldots$

Ponn (von der Ropp) Христофор-Фромгольд (Христофор Христофорович) фон дер - курляндец, бригадир 1716-1719, генерал-майор 1719-1726

Румянцев Александр Иванович - бригадир 1722-24, генерал-майор 17241727

Салтыков Семен Андреевич - бригадир 1719-1722, генерал-майор 1722-1727 
Сандерс (Saunders) Томас - англичанин, капитан-командор 1718-1721, шаутбенахт 1721-1727

Сент-Илер (Saint-Hilaire), бар. - француз, генерал-лейтенант 1715-1717

Сенявин Иван Акимович меньший - капитан-командор 1721-1725

Сенявин Наум Акимович - капитан-командор 1719-1721, шаутбенахт 17211727

Сиверс (Sivers) Петр (Питер) Иванович - датчанин, капитан-командор 17141719, шаутбенахт 1719-1721, вице-адмирал 1721-1727

Скляев Федосей Моисеевич - капитан-командор 1723-1728

Скорняков-Писарев Григорий Григорьевич - генерал-майор 1722-1723

Сукин Семен Иванович - бригадир ...1724-1728

Tрезель (Trezel) Самуил - голландец, шаутбенахт 1714-1715

Трейден Тимофей Иванович - бригадир ...1711-1726

Трубецкой Иван Юрьевич, кн. - генерал-майор ...1700, 1718-1719, генераллейтенант 1719-1722, генерал-аншеф 1722-1728

Трубецкой Юрий Юрьевич, кн. - бригадир 1719-21, генерал-майор 17211727

Урбанович Христофор - поляк, генерал-майор 1724-1727

Ушаков Андрей Иванович - бригадир 1718-1721, генерал-майор 1721-1727

Фамендин (фон Менгден) Иван Алексеевич - лифляндец (родился в России?), бригадир 1715-1726

Фамендин (фон Менгден) Юрий Андреевич - лифляндец (родился в России?), генерал-майор ...1697-1703

Фаминиьын Юрий (Егор) Иванович - поляк (родился в России), бригадир 1721-1727

Фангофm (van Hooft) Ян - голландец, капитан-командор 1717-21, шаутбенахт

1721-1726

Фастман Федор (Фердинанд) Иванович - бригадир ...1708...

Филингейм (Фихтенгейм) Иван Самуилович фон - бригадир ...-1709

Фразер (Fraser) Томас Томасович - бригадир ...1708-1709...

Фриз (Фризен) Генрих-Фридрих? де, гр. - бригадир 1707-1711

Чамберс Иван (Джон) Иванович - немец, по др. сведениям шотландец (родился

в России), генерал-майор 1701-1707, генерал-поручик 1707-1713...

Чекин Федор Гаврилович - бригадир 1708-1714, генерал-майор 1714-1725

Чернцов (Ченцов) Алексей Григорьевич - бригадир 1709-1715...

Чернышев Григорий Петрович - бригадир 1709-13, генерал-майор 1713-1725, обер-штер-кригс-комиссар флота 1715-1722

Чириков Лука Степанович - бригадир ...1710-1711, генерал-майор 1711-1715, обер-штер-кригс-комиссар 1711-1715

Шамордин Яков Сергеевич - бригадир ...1722-1725...

Шарф Александр Вилимович - немец (Саксония?), генерал-майор 1700-1705

Шаховской Андрей Федорович, кн. - генерал-квартирмейстер 1702-...

Швейден (Шведен, Швендин) Вилим Иванович фон - генерал-майор ...17061708 
Шелтинг (Scheltinga) Вейбрант - голландец, капитан-командор 1712-1717, шаутбенахт 1717-1718

Шенбек (Шомбек, Шонбек) Адам Андреевич фон - генерал-лейтенант 17031705

Шенк - генерал-майор ...-1709

Шереметев Борис Петрович, гр. - генерал-аншеф ...1700-1701, генералфельдмаршал 1701-1719

Шереметев Владимир Петрович - бригадир 1709-1725

Шереметев Михаил Борисович, гр. - генерал-майор ...1711-14

Шидловский (Шилов) Федор Владимирович - бригадир 1706-1709, генералмайор 1709-1711

Шлиппенбах (Шлифенбах) (von Schlippenbach) Вольмар-Антон фон, бар. лифляндец, генерал-майор ...1714 .., генерал-поручик ...1715-1718...

Шомбург (Шауенбург, Шомберг, Шамбурх) (von Schauenburg) Отто-Рудольф фон, гр. - немец, бригадир 1706-1707, генерал-майор 1707-1710...

Штаф, бар. - немец, бригадир ...1709-1711, генерал-майор 1711-1716...

Шток Логин Логинович - бригадир ...1720-1727

Штольи фон - генерал-майор ...1708-1709

Шувалов Иван Максимович старший - бригадир 1719-1726

Энцберг (Денсберг) Николай фон, бар. - австриец, генерал-аншеф 1710-1711

Юсупов Григорий Дмитриевич, кн. - бригадир 1711?- 1722, генерал-майор $1722-1726 \ldots$

Ягужинский Павел Иванович - Литва / Польша, генерал-майор 1717-1722, генерал-лейтенант 1722-1727

Языков Семен Иванович - генерал-провиантмейстер 1700-1701

Яковлев Петр Иванович - бригадир 1709-12, генерал-майор 1712-1717...

Янус д`Эберштедт (von Jahnus d'Eberstett) Либерехт-Готфрид фон генерал-аншеф ...1710-1711 